\title{
Synthesis and Molecular Docking Studies of some Pyrano[2,3-c] Pyrazole as an Inhibitor of SARS- Coronavirus 3CL Protease
}

\author{
Boutaina Addoum 1(D), Bouchra El Khalfi ${ }^{1(\mathbb{D})}$, Souraya Sakoui ${ }^{1}{ }^{(\mathbb{D})}$, Reda Derdak ${ }^{1 \mathbb{D}}$, Abdelhakim \\ Elmakssoudi 2, *(D), Abdelaziz Soukri 1,*(D) \\ 1 Laboratory of Physiopathology, Genetics, Molecular and Biotechnology (PGMB), Department of Biology, Faculty of \\ Sciences Aïn Chock, Research Center of Health and Biotechnology, Hassan II University, B.P 5366 Maarif, Casablanca, \\ Morocco; ab.soukri@gmail.com (A.S.); \\ 2 Laboratory of Organic Synthesis, Extraction, and Valorization, Department of Chemistry, Faculty of Sciences Aïn Chock, \\ Hassan II University, B.P 5366 Maarif, Casablanca, Morocco; \\ * Correspondence: ab.soukri@gmail.com (A.S);
}

Scopus Author ID 6603581469

Received: 28.06.2021; Revised: 20.08.2021; Accepted: 24.08.2021; Published: 11.09.2021

\begin{abstract}
The widespread global COVID-19 pandemic due to the lack of specific treatment and the urgent situation requires the use of all resources to remedy this scourge. The current study aimed to use molecular docking tools to find potential drug candidates for treatment. The pyrano[2,3-c] pyrazole 5(ae) was targeted against the Main protease $\left(\mathrm{M}^{\mathrm{pro}}\right)$, which plays a vital role in the replication and transcription of the Corona viral genome. The 3CL Protease (PDB ID 6LU7) was modeled, and the compounds were docked using Autodock Vina software, and ADMET data have been studied. All synthesized compounds were well engaged into the active site of the main protease with strong hydrogen bond interaction and a good score of energy. The $5 \mathrm{~b}$ have been classed as the best inhibitor with an energy score of $-6.2 \mathrm{kcal} / \mathrm{mol}$, similar to the one given by chloroquine $(-6.2 \mathrm{Kcal} / \mathrm{mol})$. Moreover, the molecular interaction studies showed that protease structure had multiple active site residues for all studied compounds. Our finding confirms the potential of these derivatives as lead compounds against the selected target protein of coronavirus, which needs further analysis and dynamic simulation studies to propose then develop a new antiviral treatment.
\end{abstract}

Keywords: COVID-19; docking; protease.

(C) 2021 by the authors. This article is an open-access article distributed under the terms and conditions of the Creative Commons Attribution (CC BY) license (https://creativecommons.org/licenses/by/4.0/).

\section{Introduction}

The coronavirus (Sars-Cov-2) causing COVID 19 diseases was detected for the first time in the Hubei province of china then spreading to several countries [1], which have created a real threat to the human population worldwide. In the past time, this new virus has been considered the main causal agent of respiratory disease in birds and mammals [2]. In humans, coronaviruses infect the lower respiratory tract and induce the common cold [1]. Besides that, the SARS-CoV is classified as the most virulent strain with $10-30 \%$ lethality, observed in immuno-compromised individuals and the healthy population [2-4]. This alarming situation worldwide needed the researchers' intervention to discover an effective drug therapy able to block the viral replication of this virus [1, 5-7].

The coronavirus can be defined as an enveloped and positive-stranded RNA. Its genome size is about $30 \mathrm{~kb}$, larger than any other known RNA virus [8]. This novel coronavirus (SARS- 
COV-2) encodes many important proteins such as 3CL Protease, which has been considered as the most attractive strategy in the treatment of many viruses such as hepatitis $C$ [9] and the human immunodeficiency virus (HIV) [10]. With this in mind, we selected the main $\mathrm{M}^{\text {pro }}$ of coronavirus as a suitable target for the current investigation. This chymotrypsin-like cysteine protease has been recognized for its important role in mediating the replication of this virus, cleaving polyproteins into replication-related proteins, and to process the polypeptide into functional proteins. However, when an inhibitor interacts with the amino acids of the active site, it prevents the binding of substrates and affects the biological activity of the protease [6].

Until now, chloroquine has been recognized as a potent inhibitor of sars-cov 2 by raising the $\mathrm{pH}$ of endosomal vesicles [11] inside the cells to enter this virus, thereby preventing fusion and circulation of the virus [11]. It also blocks the cytokine storm in the late phase of critically ill covid-19 patients. On the other side, the heterocyclic compounds, namely Pyrano[2,3-c] pyrazole have been used in the current study due to their wide biological deeds, including antiviral proprieties. The chemistry of these derivatives has received great interest since this pyrazole nucleus is the parent skeleton of several medicinal drugs. Pyrano[2,3-c]pyrazole derivatives showed their virucide activities against a wide spectrum of microorganisms. These compounds are used in the treatment of malaria. Furthermore, It has been proved in vitro to control the multiplication of herpes virus HSV1 [12].

Therefore, finding an inhibitor for COVID-19's protease may be the first step to beating this contagious respiratory illness. In this regard, we describe herein an attempt to use some heterocycles as new inhibitors able to limit the propagation of this viral infection. Our efforts can be added to the literature surveys on the existing drugs that showed their potential to inhibit the replication of this virus, such as Favipiravir, Ribavirin, Remdesivir, Oseltamivir, hydroxychloroquine [13], and chloroquine [13].

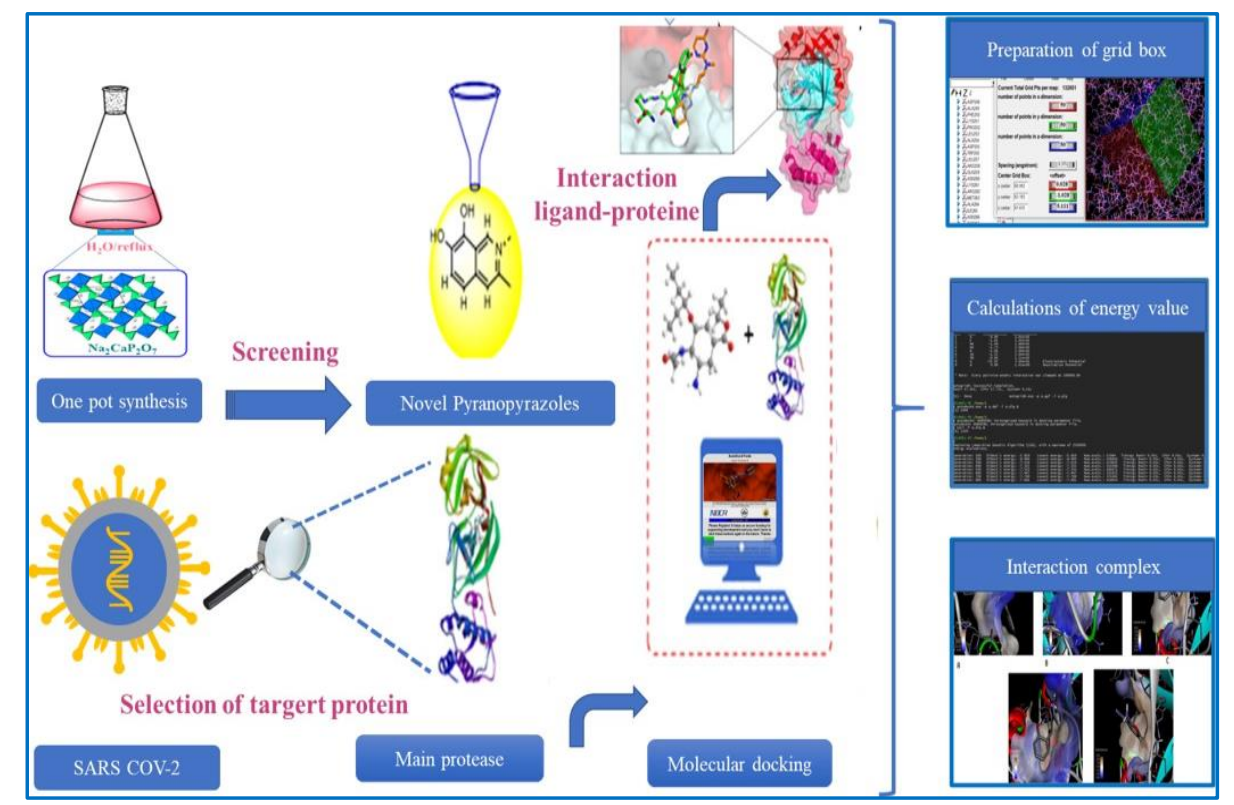

Figure 1. The hierarchical pyranopyrazoles docking protocol.

As a continuity of our previous studies on the bioactivity of the pyrano[2,3-c] pyrazole [14-16], five derivatives have been successfully synthesized and characterized, then screened for their anti-COVID-19 activity using computational tools. For this purpose, we have applied a bioinformatics approach of drug repurposing to identify possible potent inhibitors against novel Coronavirus (see figure 1). The selected compounds have been approved for their 
behavior anti-COVID19. Hence, further investigation and validation of these inhibitors against coronavirus would be very helpful to bring these molecules to clinical settings.

\section{Materials and Methods}

\subsection{Chemistry.}

2.1.2. Catalyzed synthetic route to prepare the pyrano[2,3-c] pyrazoles.

The studied pyranopyrazoles derivatives 5 was synthesized by a four-component reaction between aromatic aldehyde 1 , ethyl acetoacetate 2 , hydrazine hydrate 3 , and malononitrile 4 in the presence of the pyrophosphate $\mathrm{Na}_{2} \mathrm{CaP}_{2} \mathrm{O}_{7}$ as a catalyst according to a previously described experimental procedure as shown in figure 2 (see also figure $\mathrm{S} 1$ ). The Reaction of pyranopyrazoles 5 was monitored by thin-layer chromatography (TLC), and all products were purified by recrystallization from ethanol. After that, the synthesized compounds were characterized by melting point and spectroscopic analysis (IR, ${ }^{1} \mathrm{H}$ NMR, ${ }^{13} \mathrm{C}$ NMR) (see Figure S2-S17 in supplementary material) [17], and we checked their purity by using the HPLC technique, and the analyses were carried out on a Shimadzu LC-20AT equipped with a C18, $5 \mu \mathrm{m} \times 250 \mathrm{~mm}$ column, detection at $\lambda=254 \mathrm{~nm}$.

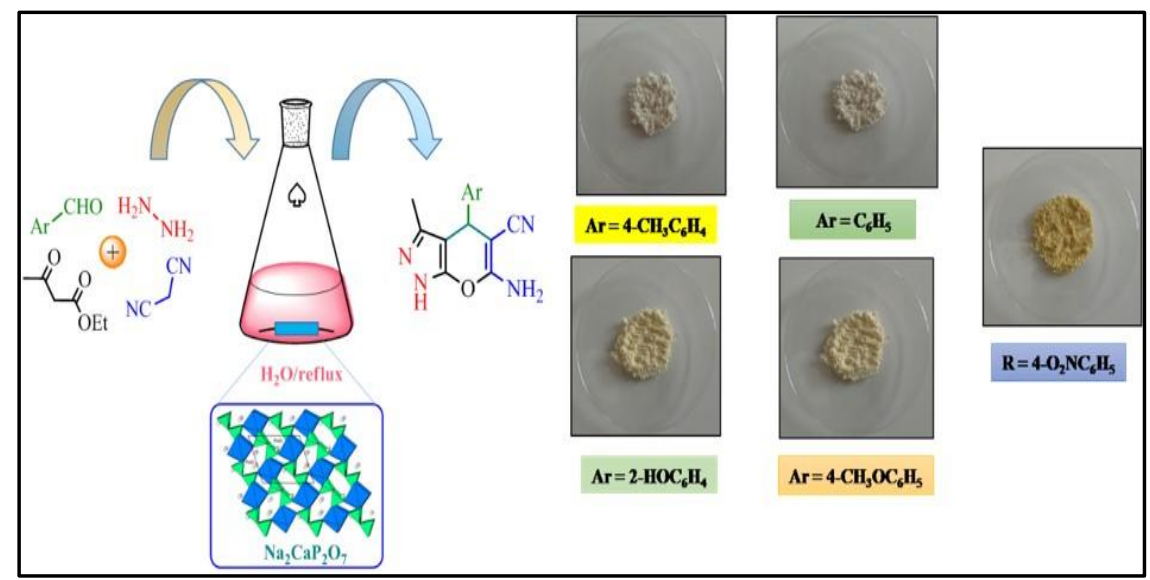

Figure 2. Synthetic route and structure of synthesized Pyrano[2,3-c] pyrazole 5(a-e).

\subsubsection{Preparation of the catalyst.}

$\mathrm{Na}_{2} \mathrm{CaP}_{2} \mathrm{O}_{7}$ was prepared as described in figure $\mathrm{S} 18$. The obtained catalyst was characterized using X-ray Diffraction (XRD) (Figure S18 and Table S1), Fourier Transform Infrared (FT-IR) spectroscopy (see Figure S19 and Table S2), Transmission Electron Microscopy(see Figure S21 and S22).

\subsubsection{Spectroscopic characterization.}

6-Amino-3-methyl-4-phenyl-1,4-dihydropyrano[2,3-c]pyrazole-5-carbonitrile (5a): White solid; m.p. $245-246{ }^{\circ} \mathrm{C}$ (lit. 244-245 $\left.{ }^{\circ} \mathrm{C}\right)$; $\mathrm{R}_{\mathrm{f}}\left(20 \%\right.$ AcOEt/hexane) 0.61; (HPLC): $\left(\mathrm{t}_{\mathrm{R}}=\right.$ $3.63 \mathrm{~min}) ;{ }^{1} \mathrm{H}$ NMR $\left(300 \mathrm{MHz}, \mathrm{DMSO}_{6}, \mathrm{ppm}\right): \delta 1.73$ (s, 3H), $4.54(\mathrm{~s}, 1 \mathrm{H}), 6.83(\mathrm{~s}, 2 \mathrm{H})$, 7.11-7.45 (m, 5H), $12.11(\mathrm{~s}, 1 \mathrm{H}) ;{ }^{13} \mathrm{C}$ NMR (75 MHz, DMSO-d $\left.6, \mathrm{ppm}\right): \delta 9.7\left(\mathrm{CH}_{3}\right), 36.2$ (pyran $\left.\mathrm{C}_{4}\right), 57.2\left(\mathrm{C}_{5}-\mathrm{CN}\right), 97.6\left(\mathrm{C}_{8}\right), 120.7(\mathrm{CN}), 126.7,127.4,127.5,128.4,128.5,135.5$ (aromatic carbons), $144.4\left(\mathrm{C}_{3}\right), 154.7\left(\mathrm{C}_{7}\right), 160.8\left(\mathrm{C}_{6}-\mathrm{NH}_{2}\right)$; IR $\left(\mathrm{KBr}, \mathrm{cm}^{-1}\right): 3473\left(\mathrm{NH}_{2}\right), 3170$ $(\mathrm{NH}), 2191(\mathrm{CN}), 1649(\mathrm{C}=\mathrm{N}), 1604(\mathrm{Ar})$. 
6-Amino-3-methyl-4-(4-methylphenyl)-1,4-dihydropyrano[2,3-c]pyrazole-5carbonitrile $5 b$ White solid; m.p. 205-207 ${ }^{\circ} \mathrm{C}$ (lit. 206-207 $\left.{ }^{\circ} \mathrm{C}\right) ; \mathrm{R}_{\mathrm{f}}(20 \%$ AcOEt/hexane) 0.7; (HPLC): $\left(\mathrm{t}_{\mathrm{R}}=3.53 \mathrm{~min}\right) ;{ }^{1} \mathrm{H}$ NMR (300 MHz, DMSO-d $\left.6, \mathrm{ppm}\right): \delta 1.75\left(\mathrm{~s}, 3 \mathrm{H}, \mathrm{CH}_{3}\right), 2,22(\mathrm{~s}$, $\left.3 \mathrm{H}, \mathrm{CH}_{3}\right), 4.51\left(\mathrm{~s}, 1 \mathrm{H}, \mathrm{C}_{4}-\mathrm{H}\right), 6.81\left(\mathrm{~s}, 2 \mathrm{H}, \mathrm{NH}_{2}\right), 7,03\left(\mathrm{~m}, 4 \mathrm{H}, \mathrm{H}_{\mathrm{Ar}}\right), 12.06(\mathrm{~s}, 1 \mathrm{H}, \mathrm{NH}) ;{ }^{13} \mathrm{C}$ NMR (75 MHz, DMSO-d 6 , ppm): $\delta 9.7\left(\mathrm{CH}_{3}\right), 20.5\left(\mathrm{CH}_{3}\right), 35.8\left(\right.$ pyran $\left.\mathrm{C}_{4}\right), 57.4\left(\mathrm{C}_{5}-\mathrm{CN}\right), 97.7$ $\left(\mathrm{C}_{8}\right), 120.7(\mathrm{CN}), 127.3-129.1,136.7$ (6 aromatic carbons), $141.4\left(\mathrm{C}_{3}\right), 154.7\left(\mathrm{C}_{7}\right), 160.7\left(\mathrm{C}_{6}\right.$ $\left.\mathrm{NH}_{2}\right)$; IR (KBr, cm $\left.{ }^{-1}\right): 3483\left(\mathrm{NH}_{2}\right), 3113(\mathrm{NH}), 2193(\mathrm{CN}), 1641(\mathrm{C}=\mathrm{N}), 1602(\mathrm{Ar})$.

6-Amino-3-methyl-4-(2-hydroxyphenyl)-1,4-dihydropyrano[2,3-c]pyrazole-5-

carbonitrile 5c White solid; m.p. 215-218 ${ }^{\circ} \mathrm{C}$; ${ }^{1} \mathrm{H}$ NMR (300 MHz, DMSO-d 6 , ppm): $\delta 1.9$ (s, $3 \mathrm{H}), 4.56(\mathrm{~s}, 1 \mathrm{H}), 6.70(2 \mathrm{H}), 6.94-7.18(\mathrm{~m}, 5 \mathrm{H}), 11.00(\mathrm{~s}, 1 \mathrm{H}) ;{ }^{13} \mathrm{C}$ NMR $\left(75 \mathrm{MHz}, \mathrm{DMSO}-\mathrm{d}_{6}\right.$, ppm): $\delta 9.85,28.64,55.06,104.95,115.1,120.79,123.53,124,25,127.55,128.93,136.52$, 148.39, 159.09, 160,08; IR (KBr, cm $\left.{ }^{-1}\right): 3448,3419,3352,2189,1660,1610$.

6-Amino-3-methyl-4-(4-methoxyphenyl)-1,4-dihydropyrano[2,3-c]pyrazole-5-

carbonitrile $5 d$ White solid; m.p. $210-212{ }^{\circ} \mathrm{C} ;{ }^{1} \mathrm{H}$ NMR $\left(300 \mathrm{MHz}, \mathrm{DMSO}-\mathrm{d}_{6}, \mathrm{ppm}\right): \delta 1.78$ (s, $3 \mathrm{H}), 3.72(\mathrm{~s}, 3 \mathrm{H}), 4.54(\mathrm{~s}, 1 \mathrm{H}), 6.83(2 \mathrm{H}), 6.86-7.08(\mathrm{~m}, 4 \mathrm{H}), 12.09(\mathrm{~s}, 1 \mathrm{H}) ;{ }^{13} \mathrm{C} \mathrm{NMR}(75$ MHz, DMSO-d $\left.\mathrm{d}_{6}, \mathrm{ppm}\right): \delta 9.66,35.51,55.00,57.9,97.89,113.79,120.69,128.44,135,64$, 136.43, 154.77, 158.01, 160.68; IR (KBr, cm $\left.{ }^{-1}\right)$ : 3483, 3255, 3113, 2193, 1643, 1602.

6-Amino-3-methyl-4-(4-nitrophenyl)-1,4-dihydropyrano[2,3-c]pyrazole-5-

carbonitrile5e Wellow solid; m.p. $248-250{ }^{\circ} \mathrm{C}$ (lit. 248-249 $\left.{ }^{\circ} \mathrm{C}\right) ; \mathrm{R}_{\mathrm{f}}(20 \%$ AcOEt/hexane) 0.64; (HPLC): $\left(\mathrm{t}_{\mathrm{R}}=3.56 \mathrm{~min}\right) ;{ }^{1} \mathrm{H} \mathrm{NMR}\left(300 \mathrm{MHz}, \mathrm{DMSO}-\mathrm{d}_{6}, \mathrm{ppm}\right): \delta 1.8\left(\mathrm{~s}, 3 \mathrm{H}, \mathrm{CH}_{3}\right), 4.51(\mathrm{~s}, 1 \mathrm{H}$, $\left.\mathrm{C}_{4}-\mathrm{H}\right), 7.05$ (s, 2H, NH $\left.\mathrm{N}_{2}\right), 7,46\left(\mathrm{~d}, 2 \mathrm{H}, \mathrm{H}_{\mathrm{Ar}}\right), 8,21$ (d, 2H, $\left.\mathrm{H}_{\mathrm{Ar}}\right), 12.20(\mathrm{~s}, 1 \mathrm{H}, \mathrm{NH}) ;{ }^{13} \mathrm{C} \mathrm{NMR}$ (75 MHz, DMSO-d 6 , ppm): $\delta 9.6\left(\mathrm{CH}_{3}\right), 35.8$ (pyran $\left.\mathrm{C}_{4}\right), 55.9\left(\mathrm{C}_{5}-\mathrm{CN}\right), 96.5\left(\mathrm{C}_{8}\right), 120.4(\mathrm{CN})$, 123.8, 124.1, 128.8, 135.8 (5 aromatic carbons), $146.3\left(\mathrm{C}_{3}\right), 152.0\left(\mathrm{C}_{7}\right), 154.6\left(\mathrm{C}_{\mathrm{Ar}}-\mathrm{NO}_{2}\right), 161.1$ $\left(\mathrm{C}_{6}-\mathrm{NH}_{2}\right)$; IR (KBr, cm $\left.{ }^{-1}\right): 3477,3228\left(\mathrm{NH}_{2}\right), 3118(\mathrm{NH}), 2196(\mathrm{CN}), 1651(\mathrm{C}=\mathrm{N}), 1595(\mathrm{Ar})$.

\subsection{Computational studies.}

2.2.1. Determination of ADMET parameters.

The ADMET parameters of the synthesized compounds 5(a-e) were calculated using the freely accessible web server Swiss ADMET (http://swissadme.ch/index.php\#undefined) [18]. These parameters provide drug likeliness and pharmacokinetic data of the selected compounds. The values of the observed properties are presented in Tables 1 S3 and S4 (see ESI part).

Table 1. The ADMET proprieties of the synthesized compounds 5(a-e).

\begin{tabular}{c|c|c|c|c} 
Compounds & Log $\mathbf{P}$ & MM & Hydrogen bond donors & Hydrogen bond acceptors \\
\hline $\mathbf{5 a}$ & 2.3 & $252.27 \mathrm{~g} / \mathrm{mol}$ & 2 & 4 \\
\hline $\mathbf{5 b}$ & 2.7 & $266.3 \mathrm{~g} / \mathrm{mol}$ & 2 & 4 \\
\hline $\mathbf{5 c}$ & 2.3 & $282.3 \mathrm{~g} / \mathrm{mol}$ & 2 & 5 \\
\hline $\mathbf{5 d}$ & 2 & $268.27 \mathrm{~g} / \mathrm{mol}$ & 3 & 5 \\
\hline $\mathbf{5 e}$ & 2.1 & $297.27 \mathrm{~g} / \mathrm{mol}$ & 2 & 6
\end{tabular}

${ }^{1}$ MM: Molar mass

2.2.2. The structure and active site of SARS-COV.

The structural data regarding the active binding site of the main protease (6LU7) can be used to design novel anti-COVID-19 inhibitors [19]. This Mpro enzyme exists in homodimer, and each monomer has three domains: domain I, II, and III [3]. The third domain and $\mathrm{N}$-terminal finger are participating in the process of dimerization (Figure 3), which controls the catalytic activity of this enzyme. The Mpro of SARS-CoV-2 processes polyproteins using 
some catalytic residues viz histidine (His 41) and cysteine (Cys145) [3]. The active site of $\mathbf{M}^{\text {pro }}$ is located between domains I and II $[1,19]$.

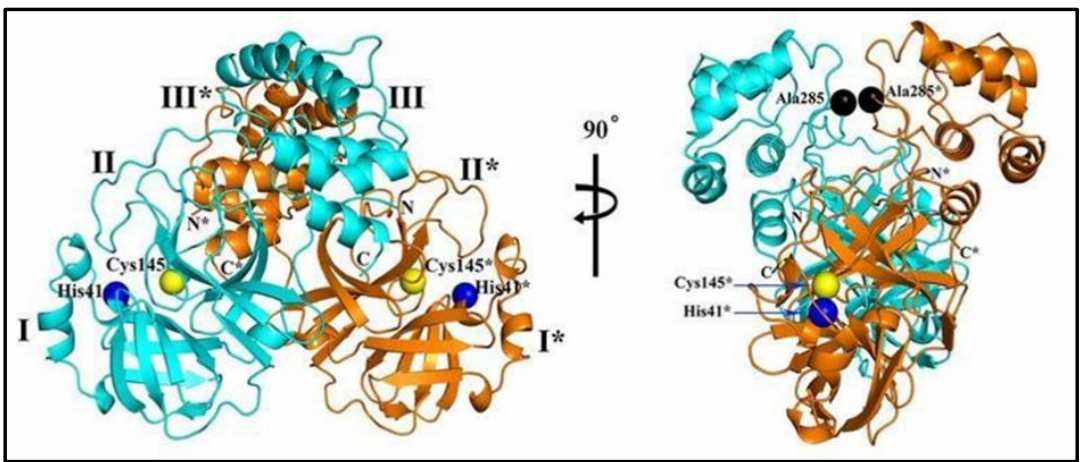

Figure 3. The 3D representation of the main protease of COVID-19. The first protomer of the dimer is marked in light blue, and the second one is shown in orange. The three representative domains are labeled by Roman numbers. The catalytic residues" Cys 145 and His 41" are represented as yellow and blue spheres.

\subsubsection{Optimization of the active site.}

The X-ray crystallographic structure of the $\mathrm{M}^{\text {pro }}$ complexed with $\mathrm{N} 3$ was obtained from the Protein Data Bank (http://www.rcsb.org/, PDB (code 6LU7) [18]. To prepare the enzyme for docking studies, polar hydrogen atoms and charges were added to the systems [5].

\subsubsection{Compound screening using Autodok Vina software.}

We stimulated the docking interaction using the software Autodock 1.5.6 (MGL tools1.5.6) [20, 21]. Polar hydrogen atoms and Kollman united charges were added to all target proteins, and the resulting file has been saved in pdbqt extension [22]. For the docking calculation, a grid box of $60 \times 60 \times 60 \AA$ in $\mathrm{x}, \mathrm{y}, \mathrm{z}$ directions were created to cover the active site of the target $[18,23,24]$. The default grid points spacing was fixed to $0.375 \AA$ and centered at $\mathrm{x}=42.527 \mathrm{y}=-46.679, \mathrm{z}=65.559$. We used the Lamarckian Genetic Algorithm (LGA) [24] for flexible docking calculations in this work. The LGA parameters including size, energy screening, mutation rate, and crossover rate. After the calculation procedure, we selected the best conformations of the complex based on their binding energy scores [25].

\subsubsection{Analysis and visualization.}

Visual analysis of the complex interaction was displayed using Discovery Studio Visualizer, and the results were validated using Autodock-tools.

\section{Results and Discussion}

\subsection{Molecular docking.}

The docking results are summarized in Table 2 showed clearly that the $5 \mathrm{~b}$ derivative was found to be the best molecule to interact at the target site with a binding affinity score similar to the chloroquine drug about $-6.20 \mathrm{Kcal} / \mathrm{mol}$. The interaction between the ligand $5 \mathrm{~b}$ and the main protease(6LU7) was stabilized by forming four hydrogen bonds with various amino acid residues, including « Cyst145, Ser144, and GLY143 ». 
Table 2. Representation of the $2 \mathrm{D}$ interaction between the tested compounds and the main protease of COVID-19.

\begin{tabular}{l|l|l} 
Ligand & Type of interaction & Binding Energy score \\
\hline $\mathbf{5 a}$ & Thr 111, Lys5, and Gln 110 & -5.4 \\
\hline $\mathbf{5 b}$ & Cyst145 Ser144 and Gly143 & -6.2 \\
\hline $\mathbf{5 c}$ & His246 Thr111 and Lys5 & -5.72 \\
\hline $\mathbf{5 d}$ & Gln 110, His 246 and Thr111 & -5.11 \\
\hline $\mathbf{5 e}$ & Lys5 Gln 127 and ASP189 & -5.14 \\
\hline Drug 1* & Thr 111 & $-6.20[19]$ \\
\hline Drug 2** & Gln 110, Thr 292, Thr 111 & $-4.20[19]$
\end{tabular}

*Chloroquine, and ** Favipiravir

Furthermore, the virtual screening of the $5 \mathrm{a}, 5 \mathrm{c}, 5 \mathrm{~d}$, and $5 \mathrm{e}$ compounds provided a good binding affinity with 6LU7 respectively $-5.4,-5.72,-5.11$, and $5.14-\mathrm{Kcal} / \mathrm{mol}$. Their energy value is better than the energy score given by favipiravir $(-4.2 \mathrm{kcal} / \mathrm{mol})$ [13]; nevertheless, the $5 \mathrm{~b}$ derivative has been considered a great inhibitor of the main protease because of its binding energy is similar to the chloroquine. Indeed, he interacted with the pocket of 6LU7 via hydrogen bonds (see figure 4), and the amino acid residues participating in the interaction are summarized in table 2 .

According to our molecular docking analysis, we can classify the inhibition potential of the synthesized compounds, ranked by their binding affinity $(\Delta \mathrm{G})$ as follow: $5 \mathrm{~b}>5 \mathrm{c}>$ $5 a>5 d>5 e$.

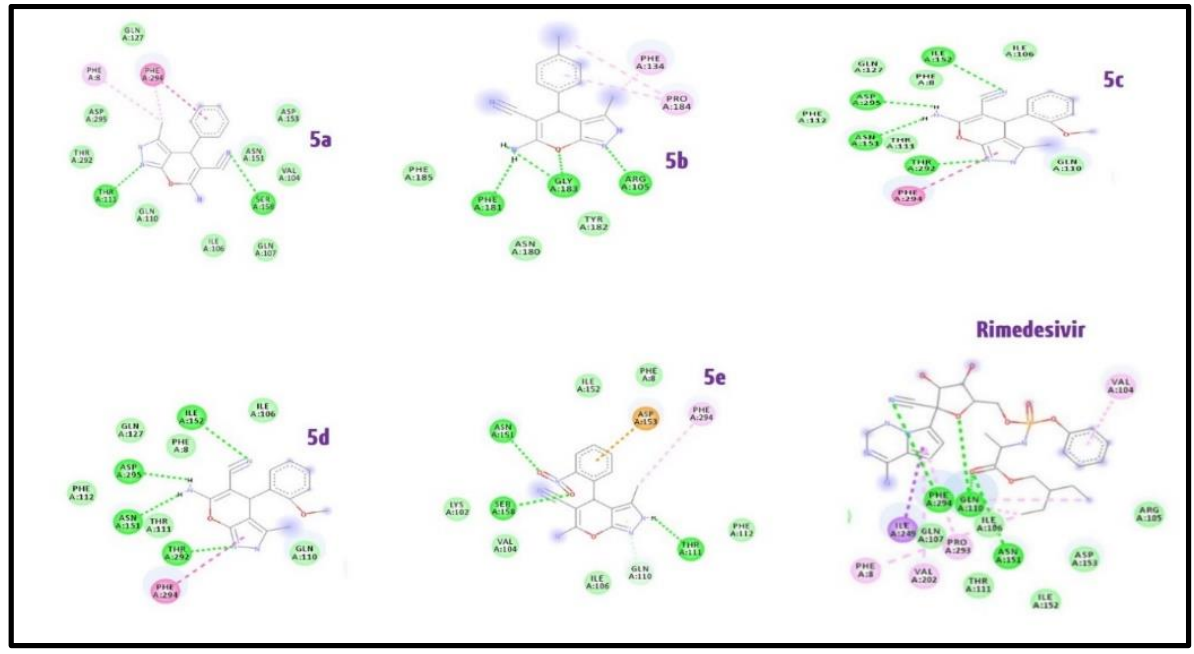

Figure 4. The ligand map showing the interaction between pyranopyrazoles 5(a-e) and residual amino acids of the main protease of COVID-19.

The $\mathrm{M}^{\text {pro }}$ of coronavirus is a good target for treating COVID-19 because it is essential for the proteolytic maturation of this virus $[3,4]$. The inhibition of $\mathrm{M}^{\mathrm{pro}}$ via blocking the active sites of the protein is one of the proposed hypotheses of the cellular mechanism of the pyrano[2,3-c] pyrazole and several drugs, including chloroquine [8] (see figure 5).

Furthermore, the $\mathrm{M}^{\text {pro }}$ structure has provided an immense opportunity to identify novel drug candidates for the treatment of coronavirus from natural products $[2,26]$ to synthetic compounds $[1,5,27]$.

In our study, we have synthesized and characterized five pyrano[2,3-c] pyrazoles compounds 5(a-e), then we screened their antiviral capacity using the Autodock virtual tool [18]. The effective compounds were selected based on their best binding affinity score with COVID-19 major protease (6LU7) [8]. 


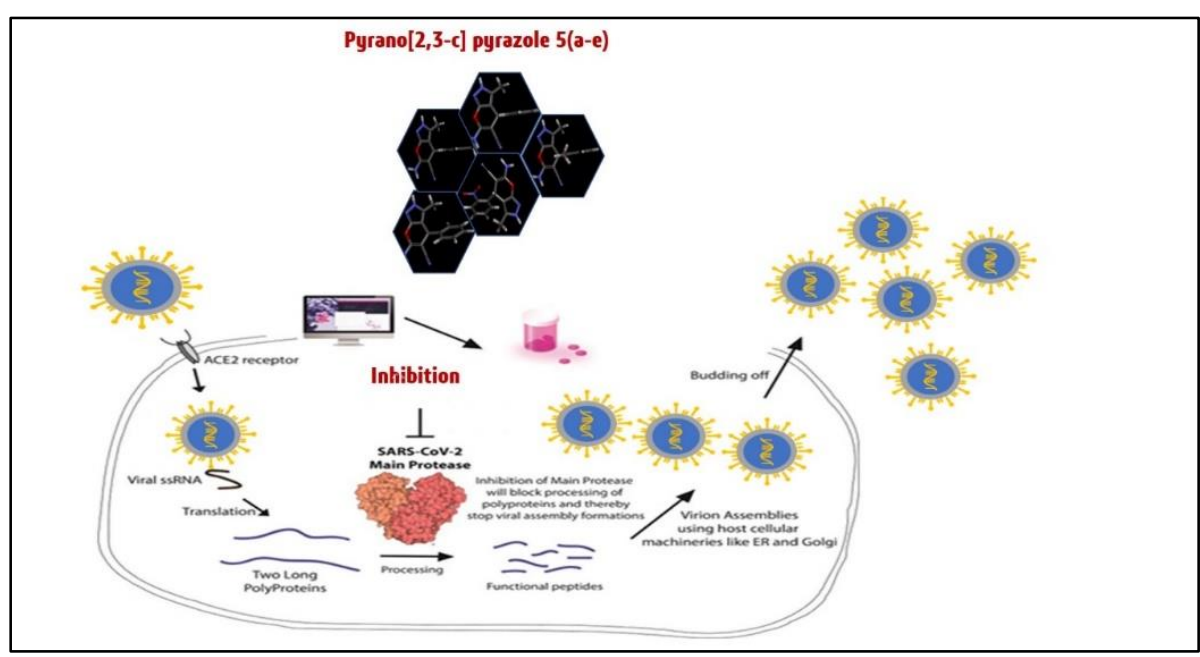

Figure 5. Representation of key points on the application of pyranopyrazoles 5(a-e) as an antiviral inhibitor.

Molecular docking can be defined as a computational tool to identify non-Covalent binding between a protein (receptor) and a selected ligand (inhibitor) [24] by predicting their mode of interaction [13] and the amino acids involved in this interaction [22]. However, we can't proceed to the virtual screening without passing by Lipinski estimation, and the selected compounds should fulfill Lipinski's rule of five [24]. Thus, the major criterion for evaluating drug likeliness proprieties of these compounds is determining their molecular parameters, including absorption, distribution, metabolism, and excretion (ADMET) [21].

In silico study revealed that all the protease inhibitor drugs got docked with negative binding energy onto the target protein. These pyranopyrazoles compounds appeared to have the best potential to act against COVID-19, especially the 5b compound that gives an energy score of $-6.2 \mathrm{Kcal} / \mathrm{mol}$, which is similar to the energy score given by chloroquine ($6.2 \mathrm{Kcal} / \mathrm{mol})$ and better than the energy score given by hydroxychloroquine $(-5.5 \mathrm{Kcal} / \mathrm{mol})$ and favipiravir $(-4.2 \mathrm{kcal} / \mathrm{mol})$. Moreover, the molecular interaction studies showed that protease structure had multiple active site residues for all studied compounds, including Gln 110, Thr 292, Thr 111, Asp 189and His 246.

In summary, innumerable and huge efforts have been taken by the scientific community to identify synthetic and natural drug candidates against the spread of SARS-CoV2. Hence, no coronavirus-specific inhibitor has accomplished a preclinical level. For that reason, the compounds reported in the current study deserve further investigation in vitro and in vivo to uncloak their antiviral proprieties.

\section{Conclusions}

This new virus has created a situation of stress in the medical and pharmaceutical sectors, for that reason, we have a strong motivation to find a potential treatment; as a consequence, our current investigation confirmed that pyrano[2,3-c] pyrazole could act as Mpro inhibitors but need to be explored for more experimental assessment regarding the development of an active anti-SARS- $\mathbf{M}^{\text {pro }}$ drug.

\section{Funding}

This research is done within the context of university research and benefits from the general funding given to the laboratory of physiopathology, molecular genetics, and biotechnology. 


\section{Acknowledgments}

The authors express their gratefulness to people that contributed to this work process.

\section{Conflicts of Interest}

The authors declare no conflict of interest.

\section{References}

1. Tahir ul Qamar, M.; Alqahtani, S.M.; Alamri, M.A.; Chen, L.-L. Structural basis of SARS-CoV-2 3CLpro and anti-COVID-19 drug discovery from medicinal plants. Journal of Pharmaceutical Analysis 2020, 10, 313-319, https://doi.org/10.1016/j.jpha.2020.03.009.

2. Chandel, V.; Raj, S.; Rathi, B.; Kumar, D. In silico identification of potent FDA approved drugs against Coronavirus COVID-19 main protease : A drug repurposing approach In silico identification of potent FDA approved drugs against Coronavirus COVID-19 main protease : A drug repurposing approach. Chem Biol Lett. 2020, 7, 166-175, https://doi.org/10.20944/preprints202003.0349.v1.

3. Zhang, L.; Lin, D.; Sun, X.; Curth, U.; Drosten, C.; Sauerhering, L.; Becker, S.; Rox, K.; Hilgenfeld, R. Crystal structure of SARS-CoV-2 main protease provides a basis for design of improved $\alpha$-ketoamide inhibitors. Science (New York, N.Y.) 2020, 368, 409-412.

4. Sharma, A.; Nandi, S.P. Identification of Potent Inhibitors of COVID-19 Main Protease Enzyme by Molecular Docking Study. ChemXiv. 2020, 1, https://doi.org/doi:10.26434/chemrxiv.12179202.v1.

5. Kadioglu, O.; Saeed, M.; Greten, H.J.; Efferth, T. Identification of novel compounds against three targets of SARS CoV-2 coronavirus by combined virtual screening and supervised machine learning. Computers in Biology and Medicine 2021, 133, https://doi.org/10.1016/j.compbiomed.2021.104359.

6. da Silva, F.M.A.; da Silva, K.P.A.; de Oliveira, L.P.M.; Costa, E.V.; Koolen, H.H.; Pinheiro, M.L.B.; de Souza, A.Q.L.; de Souza, A.D.L.J.M.d.I.O.C. Flavonoid glycosides and their putative human metabolites as potential inhibitors of the SARS-CoV-2 main protease (Mpro) and RNA-dependent RNA polymerase (RdRp). Mem Inst Oswaldo Cruz. 2020, 115, 1-8, https://doi.org/10.1590/0074-02760200207.

7. Faheem, B.K.K.; Sekhar, K.V.G.C.; Kunjiappan, S.; Jamalis, J.; Balaña-Fouce, R.; Tekwani, B.L.; Sankaranarayanan, M.J.B.c. Druggable targets of SARS-CoV-2 and treatment opportunities for COVID-19. Bioorg Chem. 2020, 104, https://doi.org/10.1016/j.bioorg.2020.104269.

8. Gentile, D.; Patamia, V.; Scala, A.; Sciortino, M.T.; Piperno, A.; Rescifina, A. Putative Inhibitors of SARSCoV-2 Main Protease from A Library of Marine Natural Products: A Virtual Screening and Molecular Modeling Study. Marine Drugs 2020, 18, https://doi.org/10.3390/md18040225.

9. Leuw , P.; Stephan, C. Protease inhibitors for the treatment of hepatitis C virus infection. GMS Infect Dis. 2017, 5, 1-14, https://doi.org/10.3205/id000034.

10. Ortega, J.T.; Serrano, M.L.; Pujol, F.H.; Rangel, H.R. Unrevealing sequence and structural features of novel coronavirus using in silico approaches: The main protease as molecular target. EXCLI journal 2020, 19, 400409, https://doi.org/10.17179/excli2020-1189.

11. Misbahi, H. Malaria: Mode of action of chloroquine and mechanism of chloroquine resistance. J Pharm Clin. 2013, 32, 143-153.

12. Rashad, A.E.; Hegab, M.I.; Abdel-Megeid, R.E.; Fathalla, N.; Abdel-Megeid, F.M.E. Synthesis and antiHSV-1 evaluation of some pyrazoles and fused pyrazolopyrimidines. European Journal of Medicinal Chemistry 2009, 44, 3285-3292, https://doi.org/10.1016/j.ejmech.2009.02.012.

13. Narkhede, R.R.; Cheke, R.S.; Ambhore, J.P.; Shinde, S.D. The Molecular Docking Study of Potential Drug Candidates Showing Anti-COVID-19 Activity by Exploring Therapeutic Targets of SARS-CoV-2. Eurasian Journal of Medicine and Oncology 2020, 4, 185-195, https://doi.org/10.14744/ejmo.2020.31503.

14. Shahbazi, S.; Ghasemzadeh, M.A.; Shakib, P.; Zolfaghari, M.R.; Bahmani, M. Synthesis and antimicrobial study of 1,4-dihydropyrano[2,3-c]pyrazole derivatives in the presence of amino-functionalized silica-coated cobalt oxide nanostructures as catalyst. Polyhedron 2019, 170, 172-179, https://doi.org/10.1016/j.poly.2019.04.063.

15. Das, D.; Banerjee, R.; Mitra, A. Bioactive and Pharmacologically important Pyrano[2,3-c]pyrazoles. Journal of Chemical and Pharmaceutical Research 2014, 6, 108-116.

16. Ismail, M.M.F.; Khalifa, N.M.; Fahmy, H.H.; Nossier, E.S.; Abdulla, M.M. Design, Docking, and Synthesis of Some New Pyrazoline and Pyranopyrazole Derivatives as Anti-inflammatory Agents. Journal of Heterocyclic Chemistry 2014, 51, 450-458, https://doi.org/10.1002/jhet.1757.

17. Maleki, B.; Nasiri, N.; Tayebee, R.; Khojastehnezhad, A.; Akhlaghi, H.A. Green synthesis of tetrahydrobenzo[b]pyrans, pyrano[2,3-c]pyrazoles and spiro[indoline-3,4'-pyrano[2,3-c]pyrazoles catalyzed by nano-structured diphosphate in water. RSC Advances 2016, 6, 79128-79134, https://doi.org/10.1039/C6RA15800E. 
18. Mothay, D.; Ramesh, K.V. Binding site analysis of potential protease inhibitors of COVID-19 using AutoDock. VirusDisease 2020, 31, 194-199, https://doi.org/10.1007/s13337-020-00585-z.

19. Aanouz, I.; Belhassan, A.; El-Khatabi, K.; Lakhlifi, T.; El-ldrissi, M.; Bouachrine, M. Moroccan Medicinal plants as inhibitors against SARS-CoV-2 main protease: Computational investigations. Journal of Biomolecular Structure and Dynamics 2021, 39 39, https://doi.org/doi:10.1080/07391102.2020.1758790.

20. An, T.N.M.; Alam, M.; Son, N.V.; Cuong, N.V.; Quang, N.M.; Tri, M.D.; Tan, L.V. Synthesis, Physical Chemistry, Molecular Docking, Bioactivities and Antioxidant Activity of $\alpha$-Amino Phosphonates Based on Phenothiazine Using PEG-400 as Green Catalyst. ChemistrySelect 2019, 4, 8915-8920, https://doi.org/10.1002/slct.201901560.

21. Bouchentouf, S.; Missoum, N. Identification of Compounds from Nigella Sativa as New Potential Inhibitors of 2019 Novel Coronasvirus ( Covid-19 ): Molecular Docking Study. Med Chem. 2020, 1, 1-11, https://doi.org/10.26434/chemrxiv.12055716.v1.

22. Shakil, S. A simple click by click protocol to perform docking: AutoDock 4.2 made easy for nonbioinformaticians. Excli J. 2013, 12, 831-857.

23. Datar, P.A.; Jadhav, S.R. Design and Synthesis of Pyrazole-3-one Derivatives as Hypoglycaemic Agents. International Journal of Medicinal Chemistry 2015, 2015, 1-10, https://doi.org/10.1155/2015/670181.

24. Vinodhkumar, G. Pyrazole Based Inhibitors against Enzymes of Staphylococcus aureus: A Computational Study. Journal of Proteomics \& Bioinformatics 2015, 8, 1-8, https://doi.org/10.4172/jpb.1000362.

25. Peele, K.A.; Potla Durthi, C.; Srihansa, T.; Krupanidhi, S.; Ayyagari, V.S.; Babu, D.J.; Indira, M.; Reddy, A.R.; Venkateswarulu, T.C. Molecular docking and dynamic simulations for antiviral compounds against SARS-CoV-2: A computational study. Informatics in Medicine Unlocked 2020, 19, https://doi.org/10.1016/j.imu.2020.100345.

26. Prasanth, D.S.N.B.K.; Murahari, M.; Chandramohan, V.; Panda, S.P.; Atmakuri, L.R.; Guntupalli, C. In silico identification of potential inhibitors from Cinnamon against main protease and spike glycoprotein of SARS CoV-2. Journal of Biomolecular Structure and Dynamics 2021, 39, 4618-4632, https://doi.org/10.1080/07391102.2020.1779129.

27. Plewczynski, D.; Hoffmann, M.; Von Grotthuss, M.; Ginalski, K.; Rychewski, L. In Silico Prediction of SARS Protease Inhibitors by Virtual High Throughput Screening. Chemical Biology \& Drug Design 2007, 69, 269-279, https://doi.org/10.1111/j.1747-0285.2007.00475.x. 


\section{Supplementary files}

\section{General information}

The crystalline structure of the $\mathrm{Na}_{2} \mathrm{CaP}_{2} \mathrm{O}_{7}$ was identified by using X-ray diffraction analysis (XRD) (Bruker D8 Advance $\mathrm{X}$-ray diffractometer with $\mathrm{Cu}-\mathrm{K} \alpha$ radiation: $\lambda=1.5406$ $\mathrm{A}^{\circ}$ ). The melting point of the pyranopyrazoles derivatives was determined using a Buchi 510 apparatus. The NMR spectra of ${ }^{1} \mathrm{H}$ and ${ }^{13} \mathrm{C}$ were recorded on a Bruker $300 \mathrm{MHz}$ in DMSO-d 6 . The chemical shifts $(\delta)$ are expressed in ppm. The IR spectra of the samples were acquired as $\mathrm{KBr}$ pellets on FTIR (IR Affinity - 1S, Fourier Transform Infrared Spectrophotometer, SHIMADZU). Analytical thin-layer chromatography was performed with Silica on TLC Alu foils purchased from Sigma Aldrich. Visualization of the developed chromatogram was performed by UV light $(254 \mathrm{~nm})$. All reactions were carried out under air. Solvents and starting materials (Aldrich) were used without further purification.

\section{General procedure for preparation of pyranopyrazoles 5a-e}

The catalyst $\mathrm{Na}_{2} \mathrm{CaP}_{2} \mathrm{O}_{7}(20 \mathrm{~mol} \%)$ was added to a mixture of the aldehydes ( $\left.1 \mathrm{mmol}\right)$, ethyl acetoacetate $(1 \mathrm{mmol})$, malononitrile $(1.2 \mathrm{mmol})$, and hydrazine hydrate $(2 \mathrm{mmol})$, and 1 $\mathrm{ml}$ of water in a $5 \mathrm{ml}$ flask fitted with a reflux condenser. The resulting mixture was heated to reflux (an oil bath) with stirring for $20 \mathrm{~min}$. Acetone $(2 \mathrm{ml})$ was added and the mixture was stirred for $2 \mathrm{~min}$. The products and catalyst were isolated as described above and recrystallized from $96 \%$ ethanol $(20 \mathrm{ml})$ to afford pyrano[2,3-c]pyrazoles 5a-e.

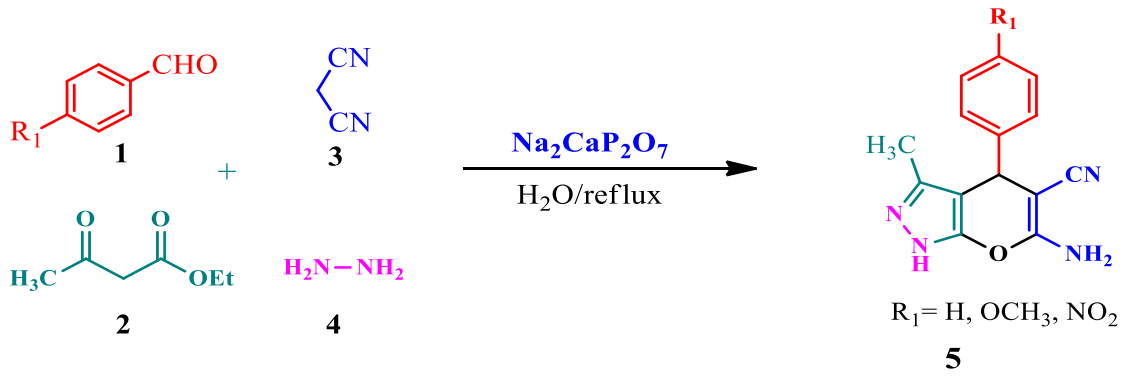

Figure S1. The synthesis of pyranopyrazoles catalyzed by $\mathrm{Na}_{2} \mathrm{CaP}_{2} \mathrm{O}_{7}$.

\section{Characterization of the compounds}

6-Amino-3-methyl-4-(2-hydroxyphenyl)-1,4-dihydropyrano[2,3-c]

pyrazole-5carbonitrile 5a

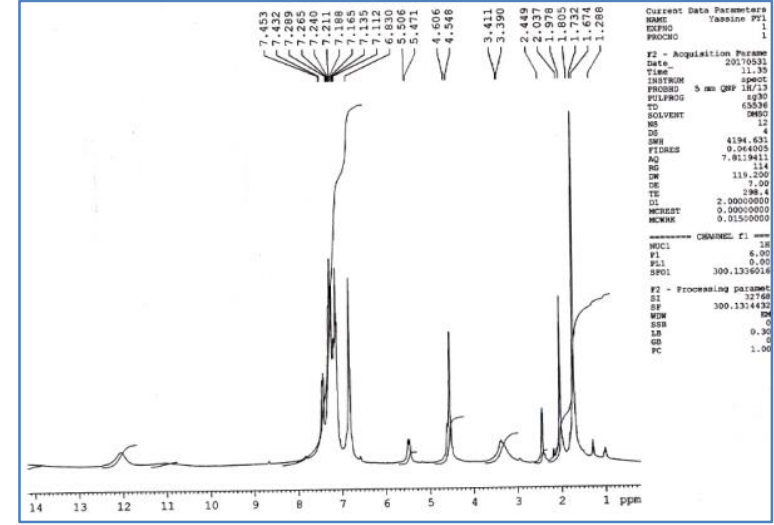

Figure S2. NMR ${ }^{1} \mathrm{H}$ of pyranopyrazoles $5 \mathrm{a}$. 
6-Amino-3-methyl-4-(2-hydroxyphenyl)-1,4-dihydropyrano[2,3-c]

pyrazole-5carbonitrile $\mathbf{5 b}$.

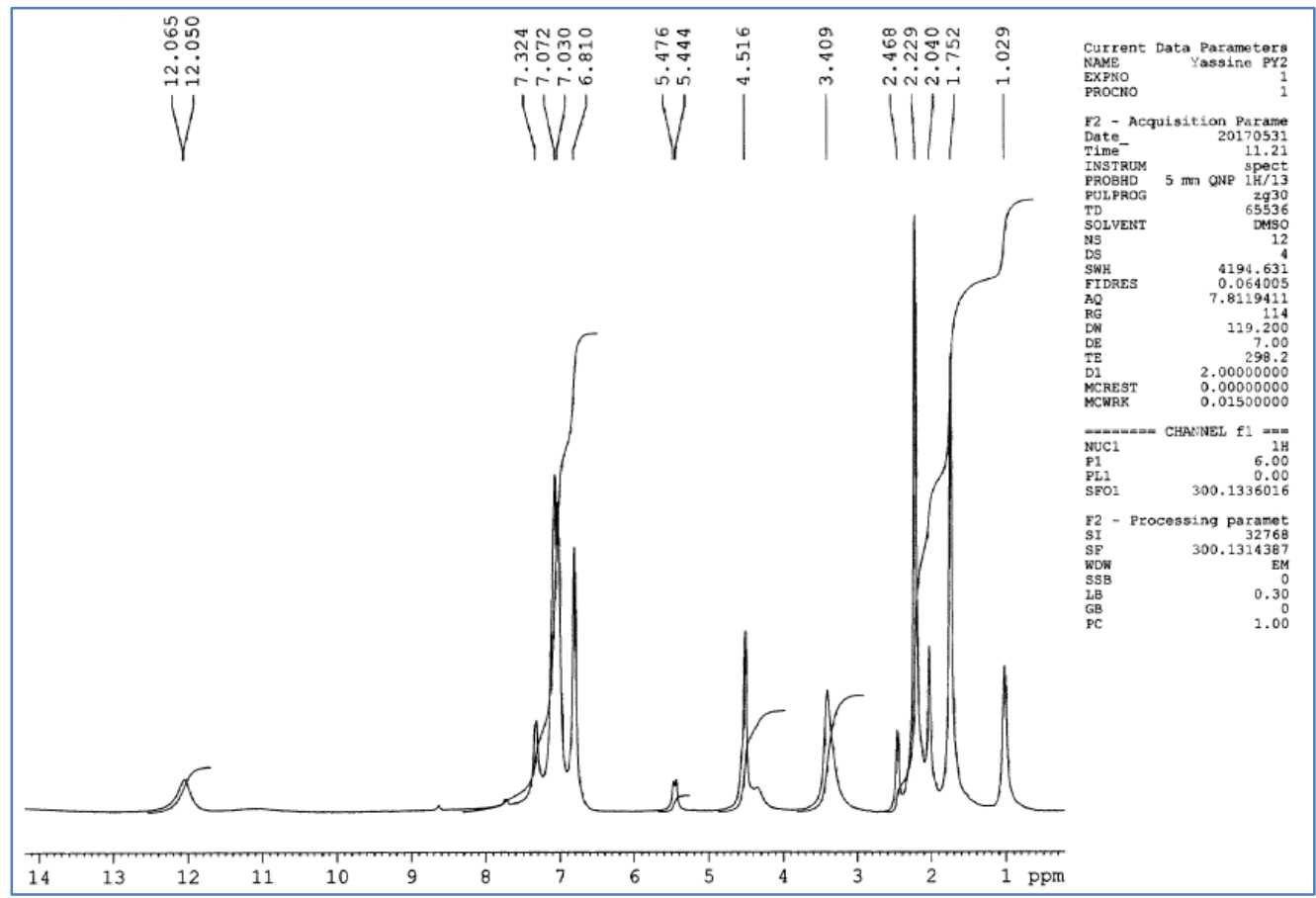

Figure S3. NMR ${ }^{1} \mathrm{H}$ of pyranopyrazoles $\mathbf{5 b}$.

6-Amino-3-methyl-4-(2-hydroxyphenyl)-1,4-dihydropyrano[2,3-c]

pyrazole-5carbonitrile 5c.

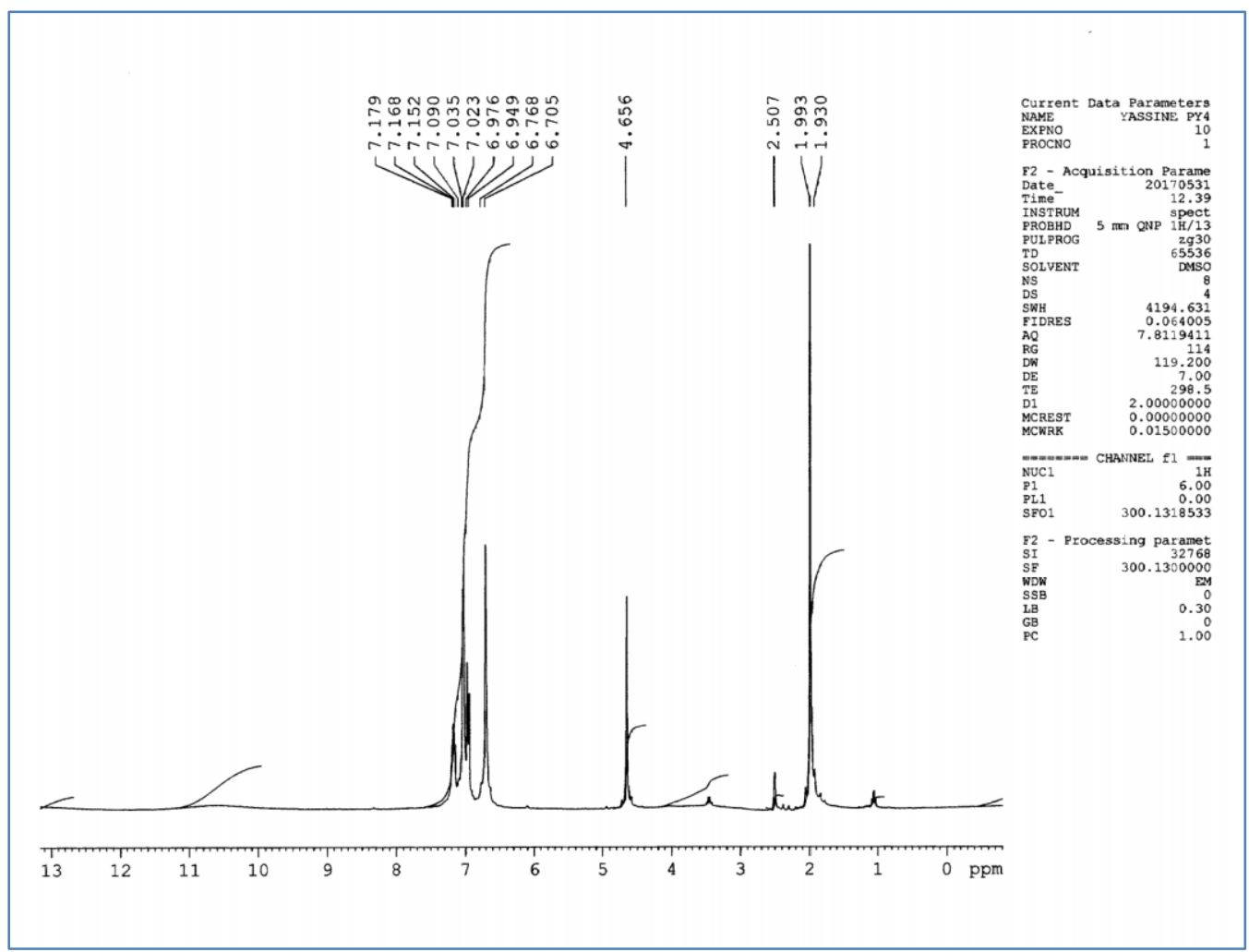

Figure S4. NMR ${ }^{1} \mathrm{H}$ of pyranopyrazoles $5 c$. 
6-Amino-3-methyl-4-(4-methoxyphenyl)-1,4-dihydropyrano[2,3-c] pyrazole-5carbonitrile 5d.

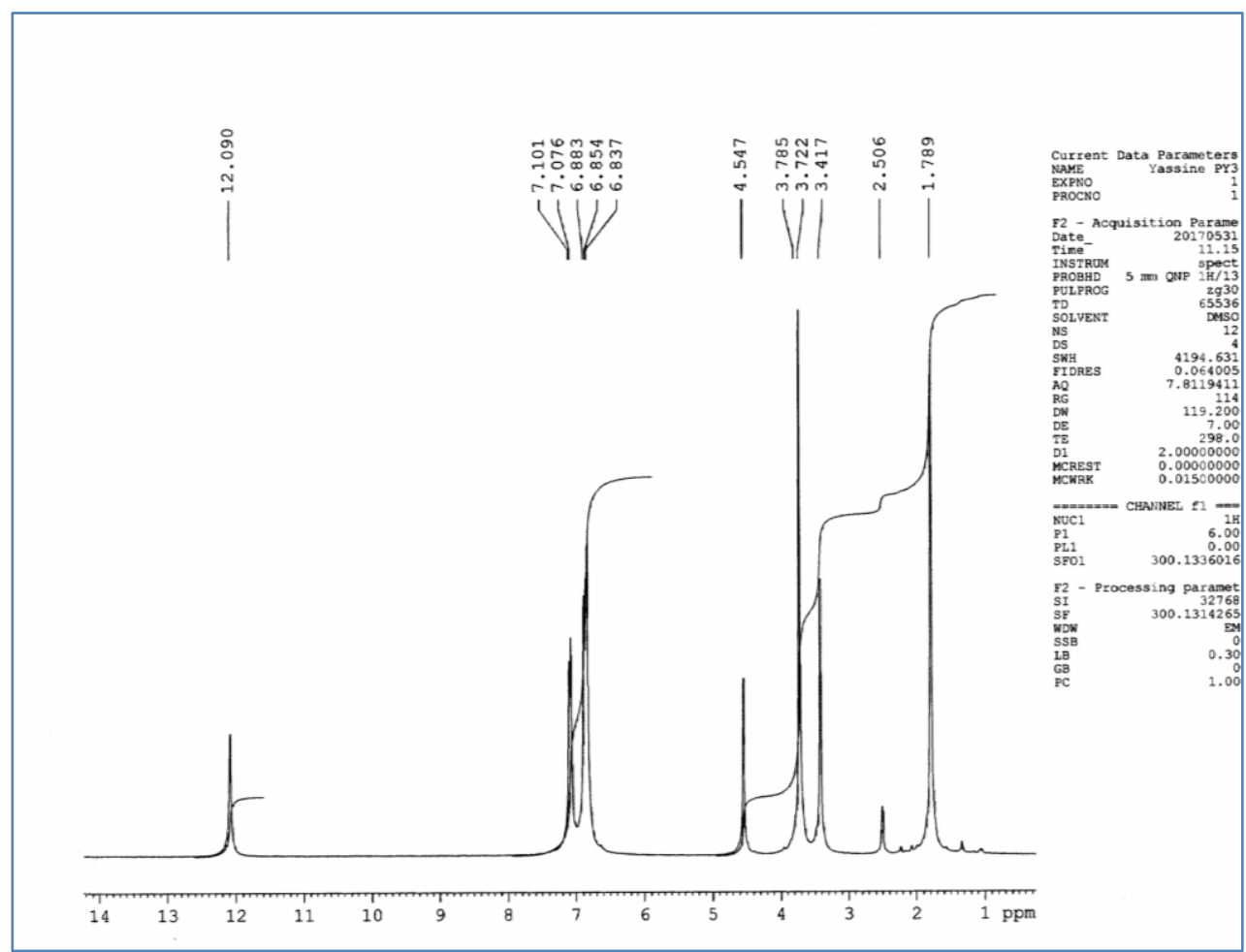

Figure S5. NMR ${ }^{1} \mathrm{H}$ of pyranopyrazoles $\mathbf{5 d}$.

6-Amino-3-methyl-4-(4-methoxyphenyl)-1,4-dihydropyrano[2,3-c]

pyrazole-5carbonitrile 5e.

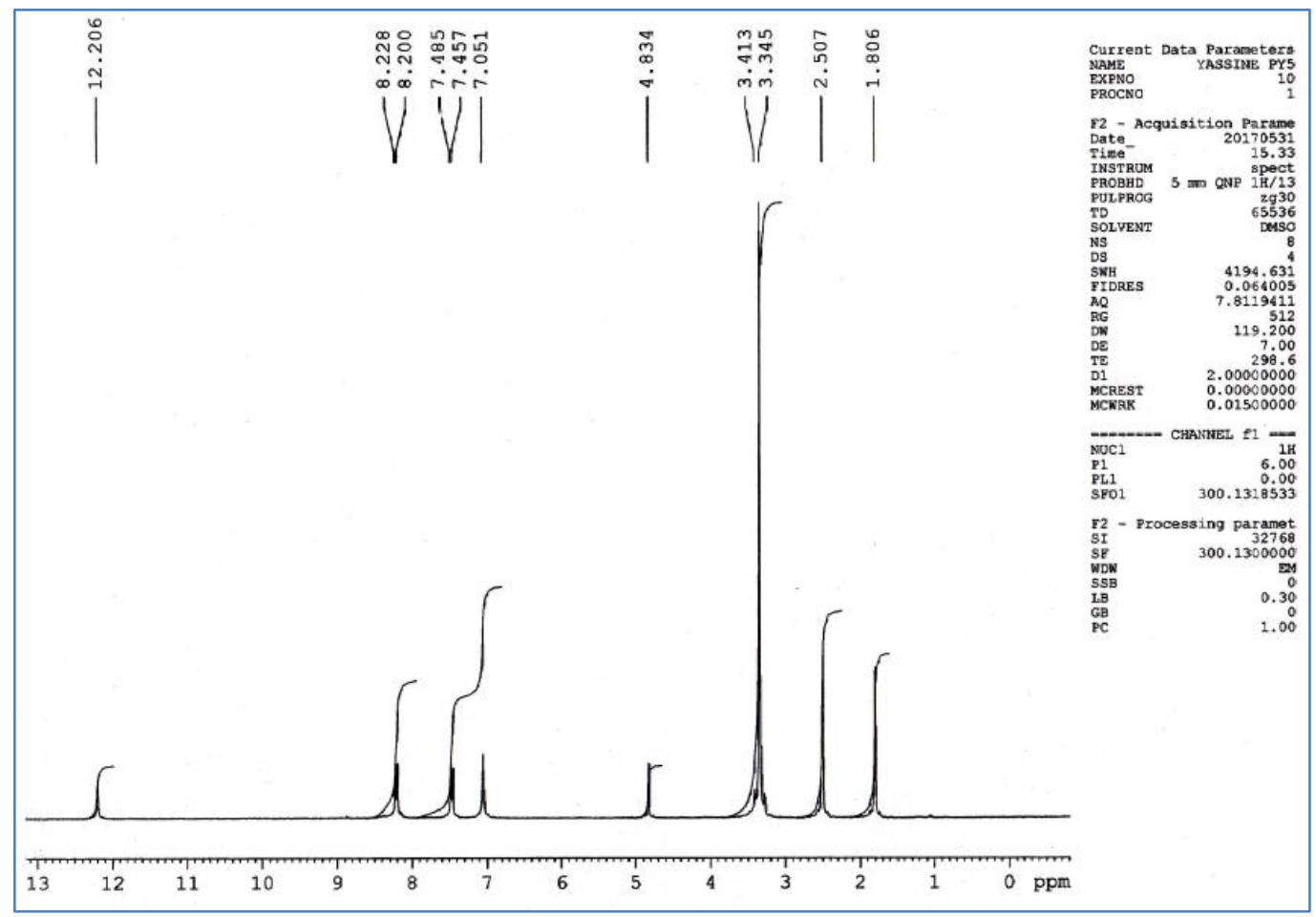

Figure S6. NMR ${ }^{1} \mathrm{H}$ of pyranopyrazoles $5 e$. 
6-Amino-3-methyl-4-(2-hydroxyphenyl)-1,4-dihydropyrano[2,3-c] pyrazole-5carbonitrile 5a.

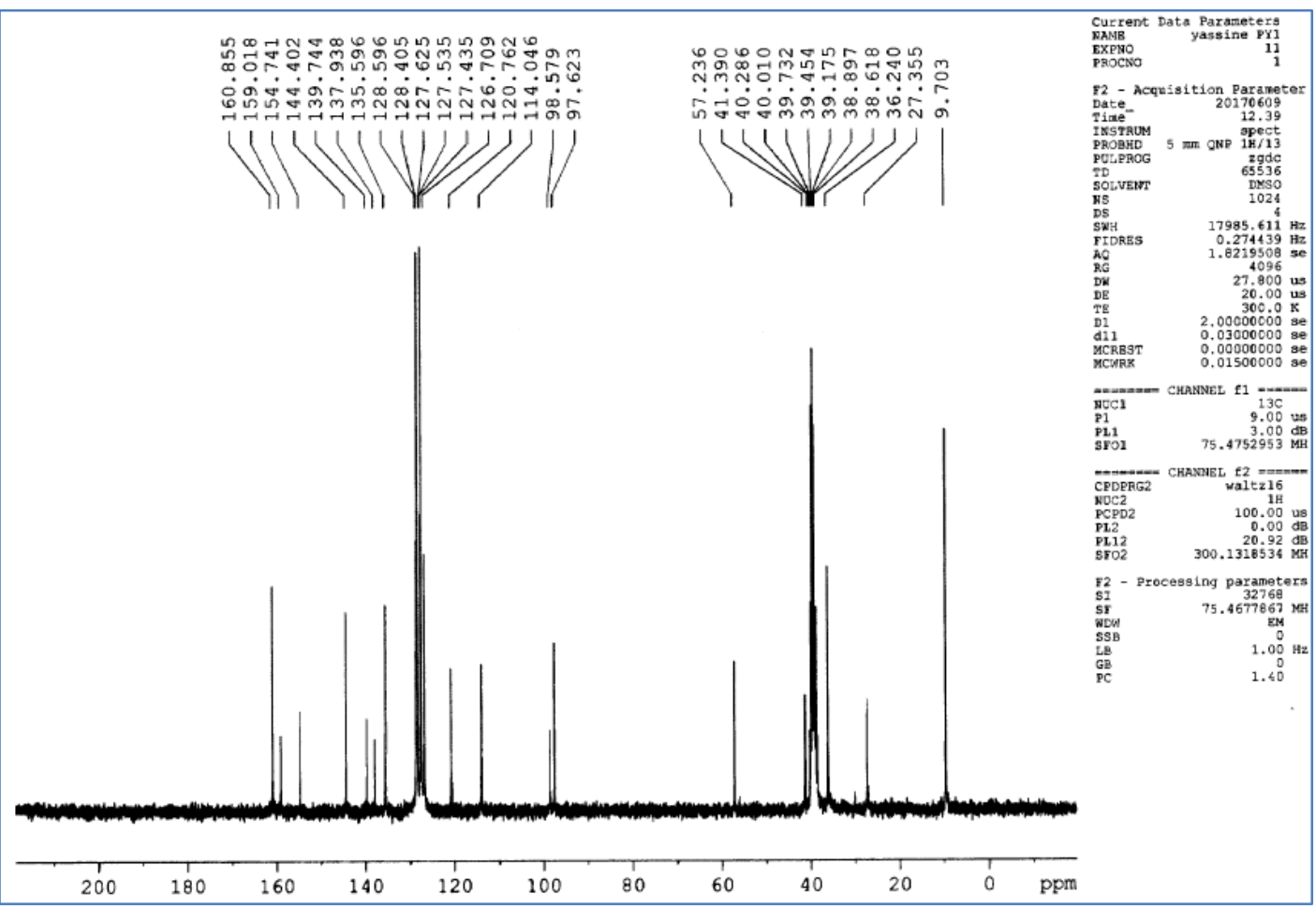

Figure S7. NMR ${ }^{13} \mathrm{C}$ of pyranopyrazoles compound 5a.

6-Amino-3-methyl-4-(2-hydroxyphenyl)-1,4-dihydropyrano[2,3-c]

pyrazole-5carbonitrile $\mathbf{5 b}$.

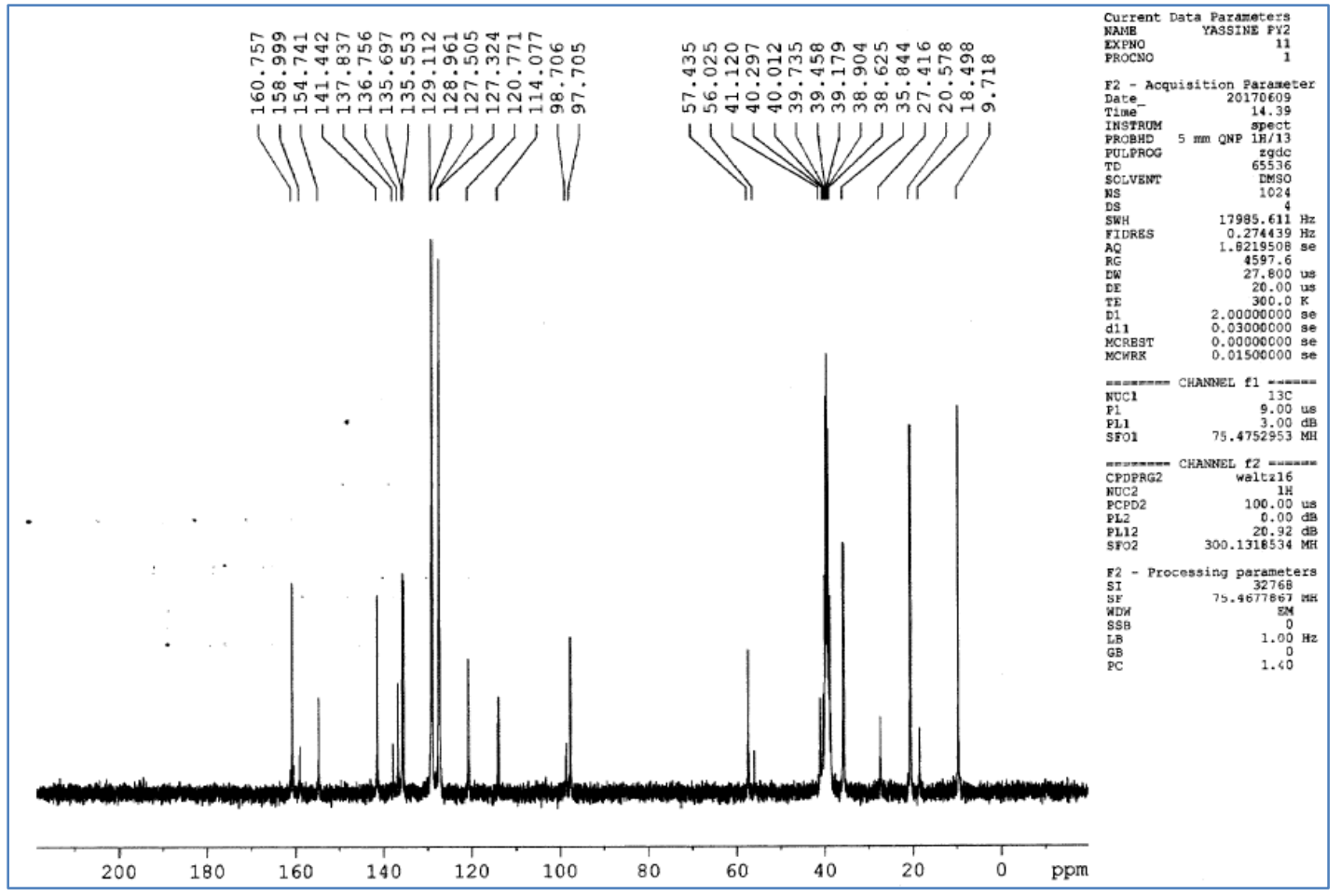

Figure S8. NMR ${ }^{13} \mathrm{C}$ of pyranopyrazoles compound $\mathbf{5 b}$. 
6-Amino-3-methyl-4-(2-hydroxyphenyl)-1,4-dihydropyrano[2,3-c]

pyrazole-5-

carbonitrile 5c.

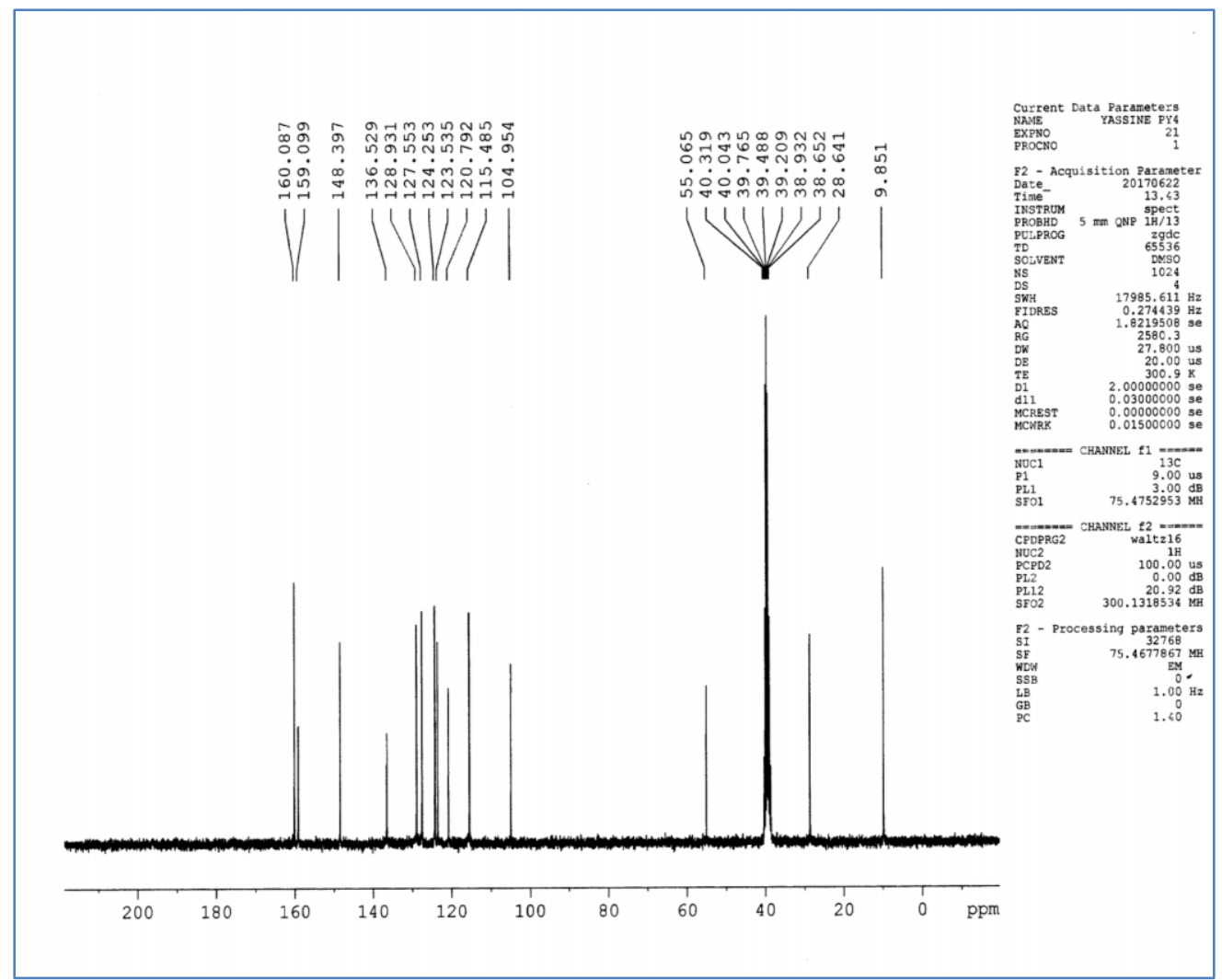

Figure S9. NMR ${ }^{13} \mathrm{C}$ of pyranopyrazoles compound $\mathbf{5 c}$.

6-Amino-3-methyl-4-(4-methoxyphenyl)-1,4-dihydropyrano[2,3-c] pyrazole-5carbonitrile 5d.

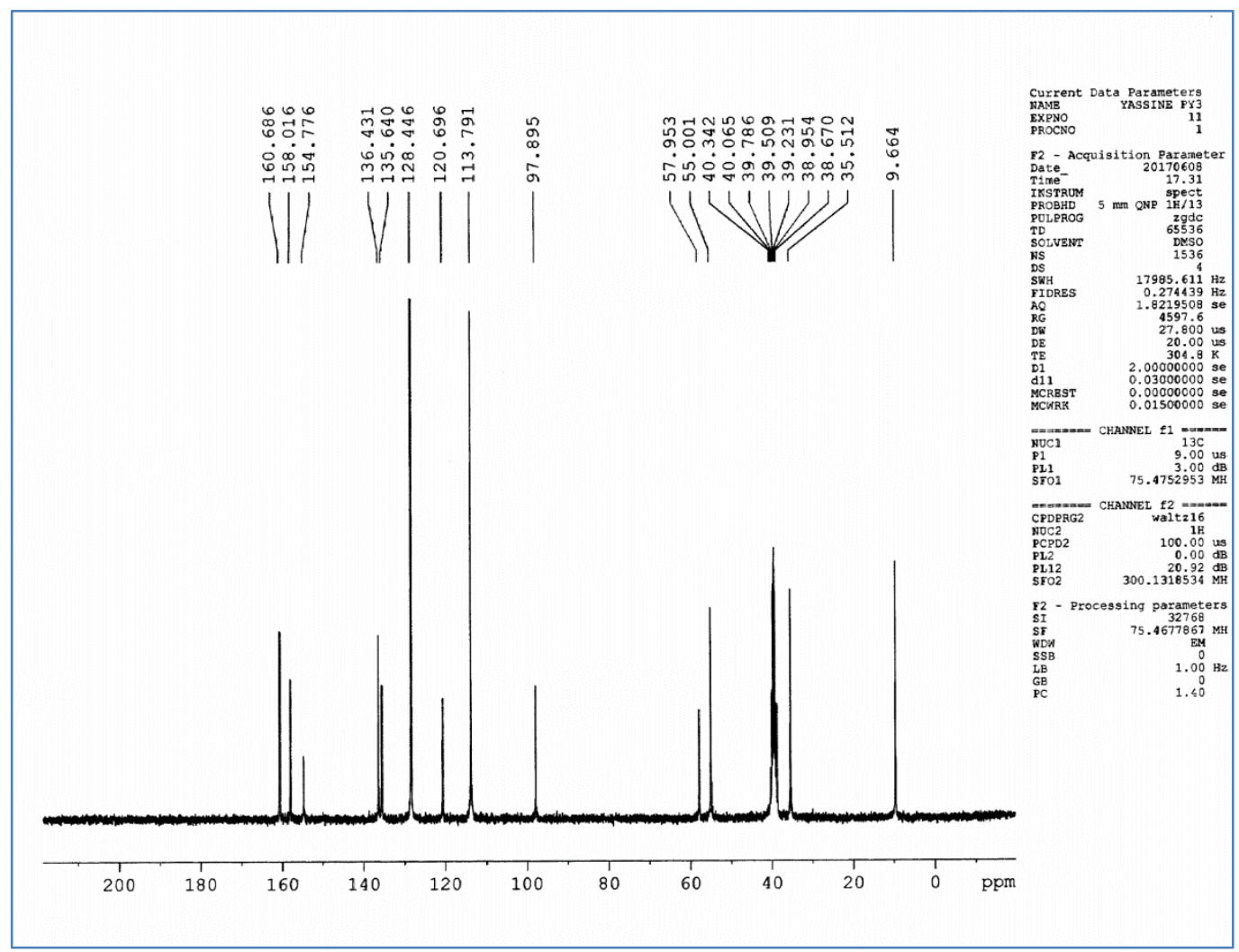

Figure S10. NMR ${ }^{13} \mathrm{C}$ of pyranopyrazoles compound $\mathbf{5 d}$. 
6-Amino-3-methyl-4-(2-hydroxyphenyl)-1,4-dihydropyrano[2,3-c] pyrazole-5carbonitrile 5e.

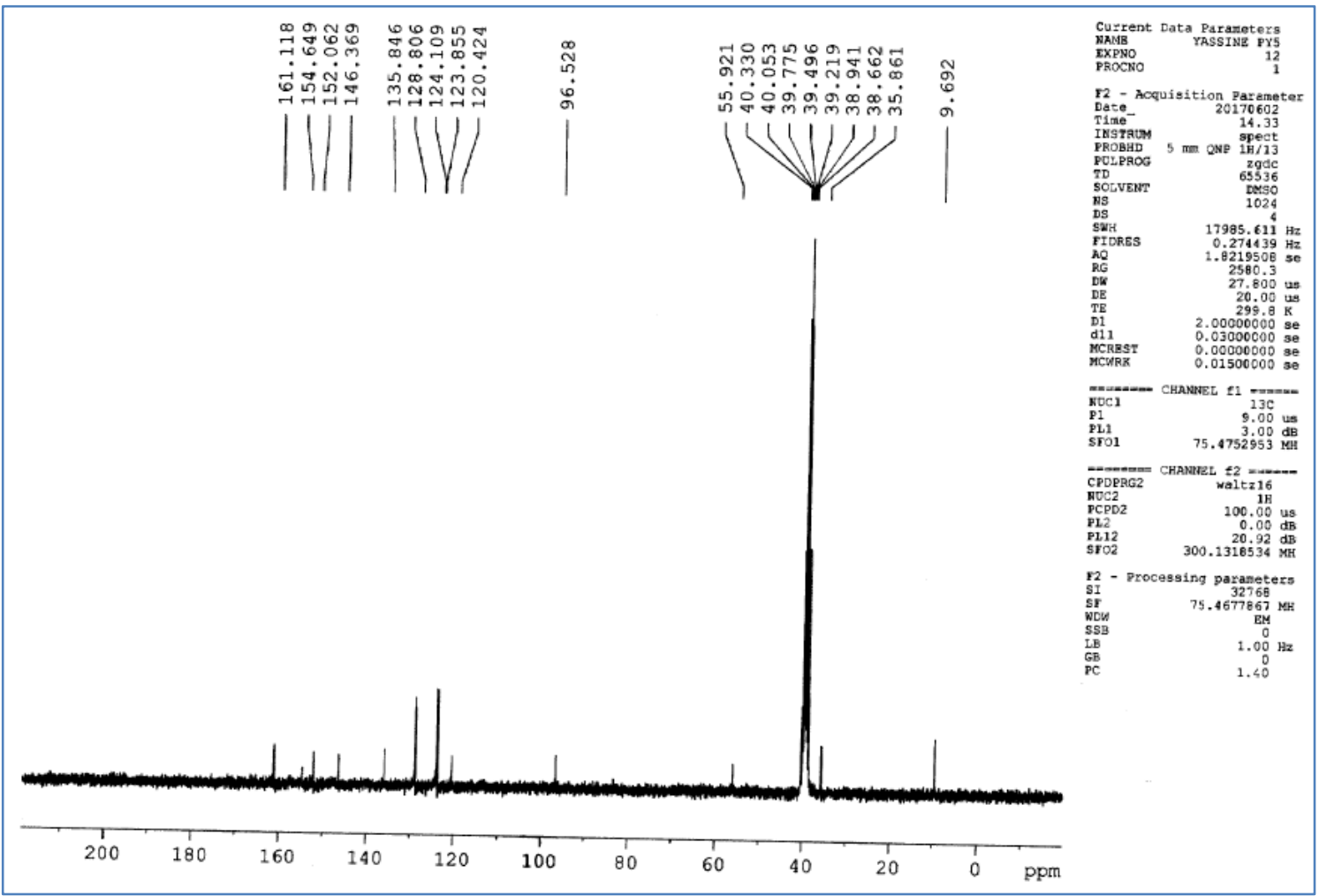

Figure S11. NMR ${ }^{13} \mathrm{C}$ of pyranopyrazoles compound $5 \mathbf{e}$.

6-Amino-3-methyl-4-(2-hydroxyphenyl)-1,4-dihydropyrano[2,3-c] pyrazole-5-carbonitrile 5a

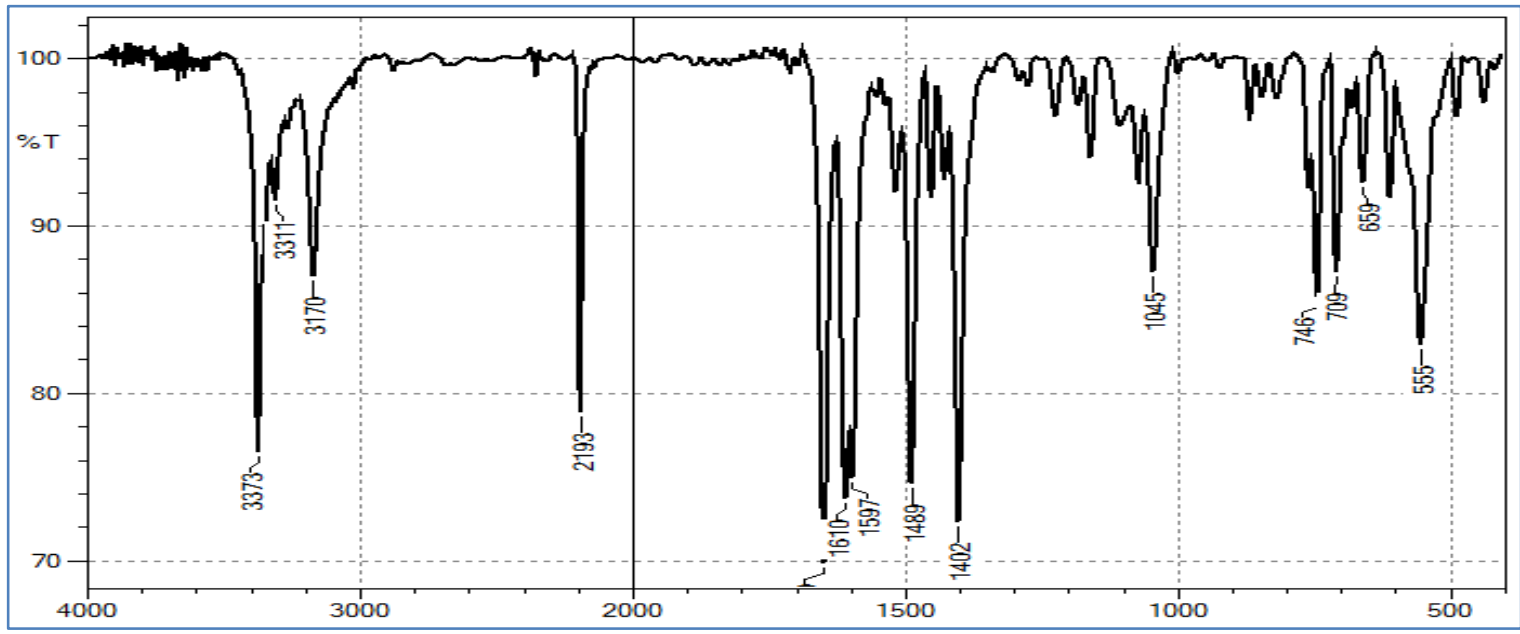

Figure S12. IR pattern of the synthesized compound of $\mathbf{5 a}$.

6-Amino-3-methyl-4-(2-hydroxyphenyl)-1,4-dihydropyrano[2,3-c]

pyrazole-5carbonitrile $\mathbf{5 b}$. 


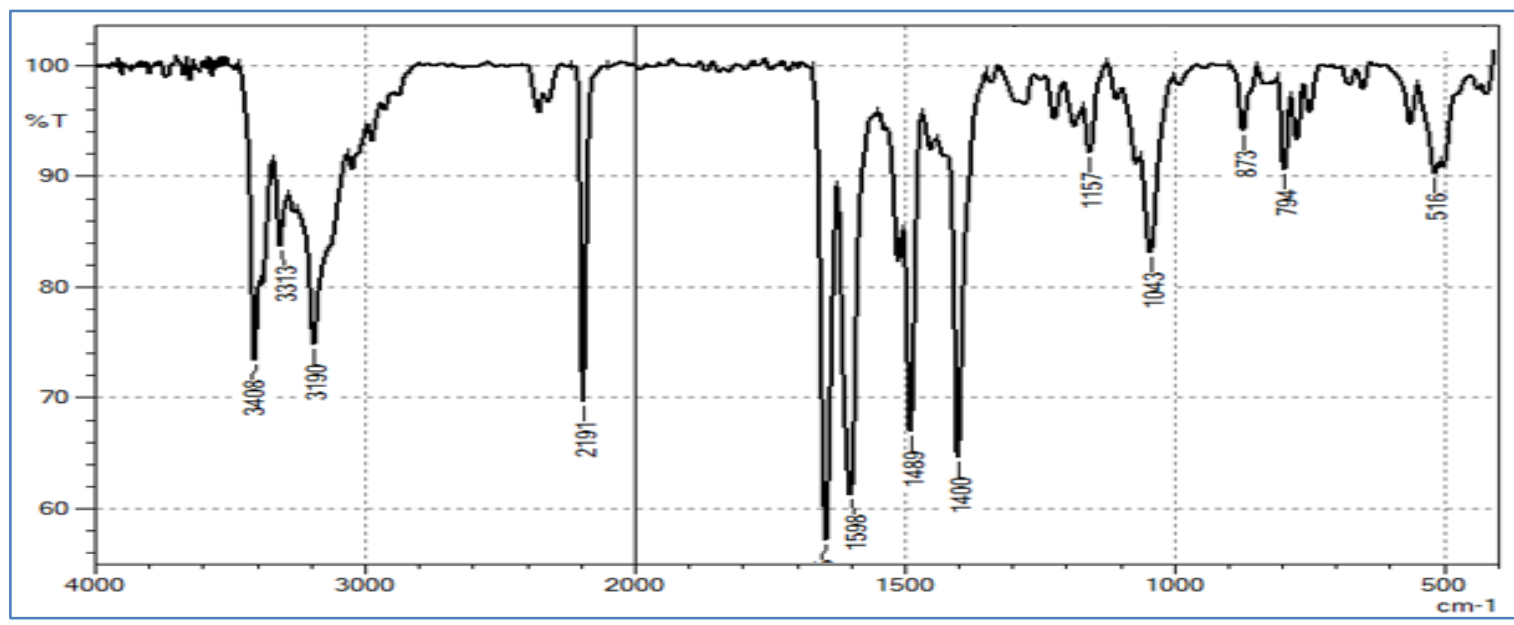

Figure S13. IR pattern of the synthesized compound of $\mathbf{5 b}$.

6-Amino-3-methyl-4-(2-hydroxyphenyl)-1,4-dihydropyrano[2,3-c] pyrazole-5carbonitrile $\mathbf{5 c}$.

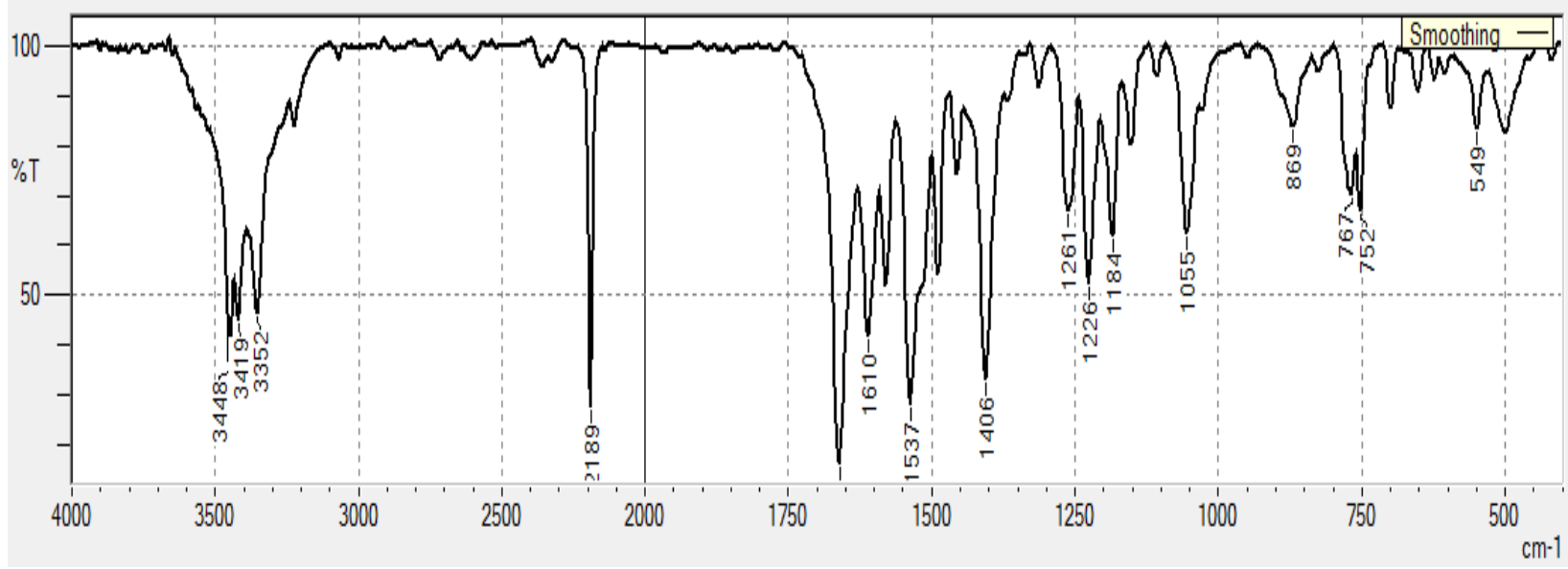

Figure S14. IR pattern of the synthesized compound 5c.

6-Amino-3-methyl-4-(4-methoxyphenyl)-1,4-dihydropyrano[2,3-c]

pyrazole-5-

carbonitrile 5d.

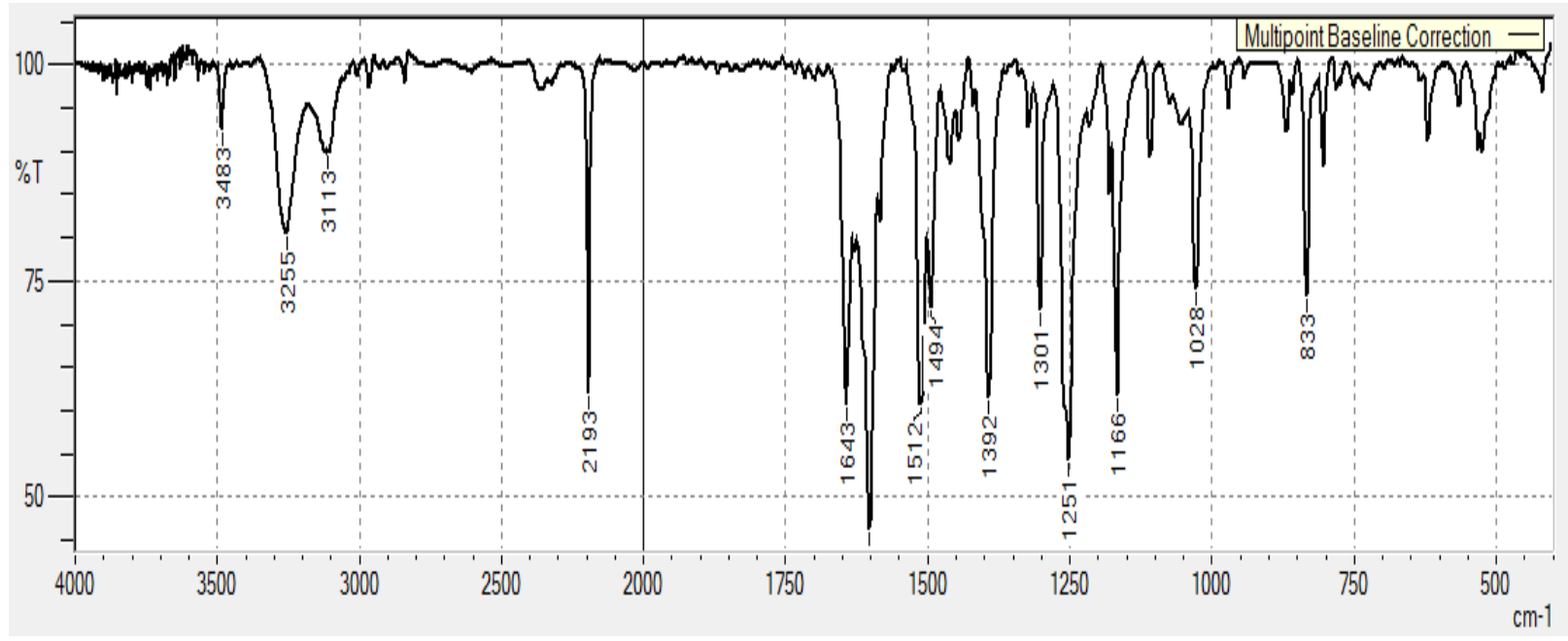

Figure S15. IR pattern of the synthesized compound 5d. 
6-Amino-3-methyl-4-(4-methoxyphenyl)-1,4-dihydropyrano[2,3-c]

pyrazole-5-

carbonitrile 5e.

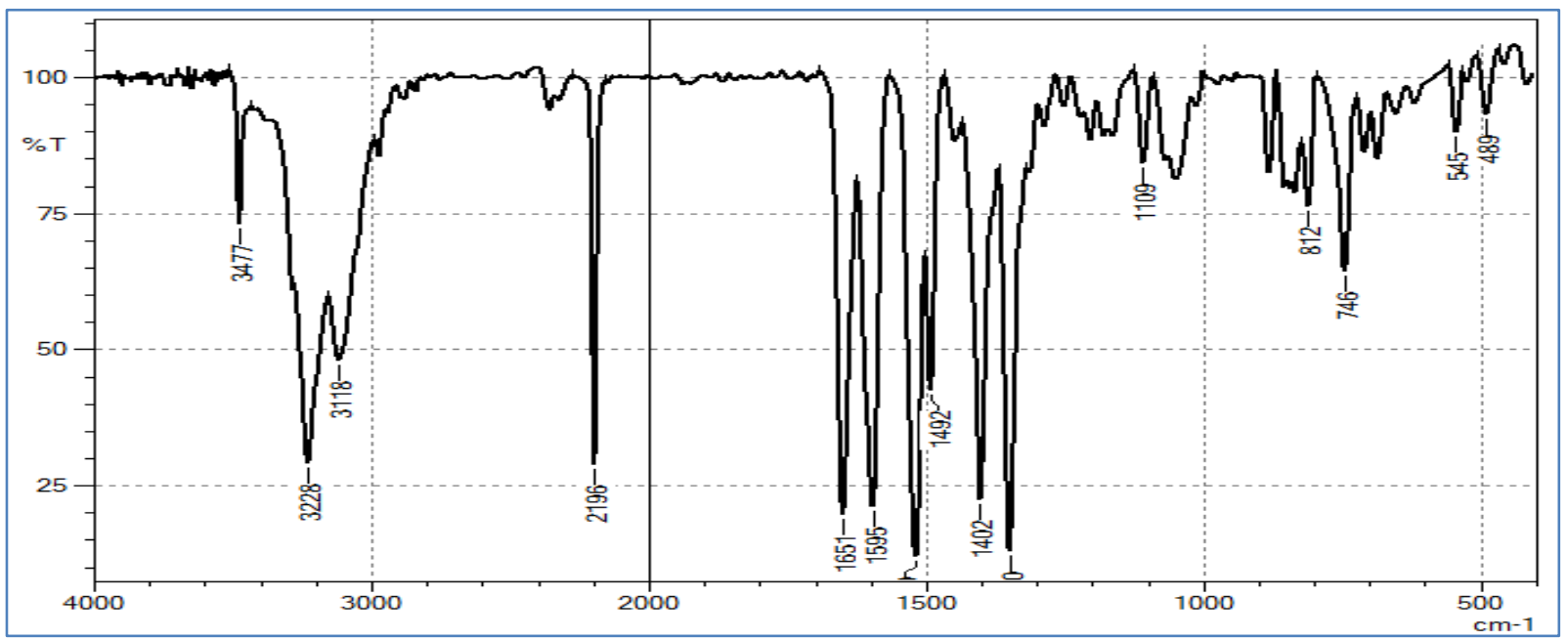

Figure S16. IR pattern of the synthesized compound $\mathbf{5 e}$.

HPLC Analysis
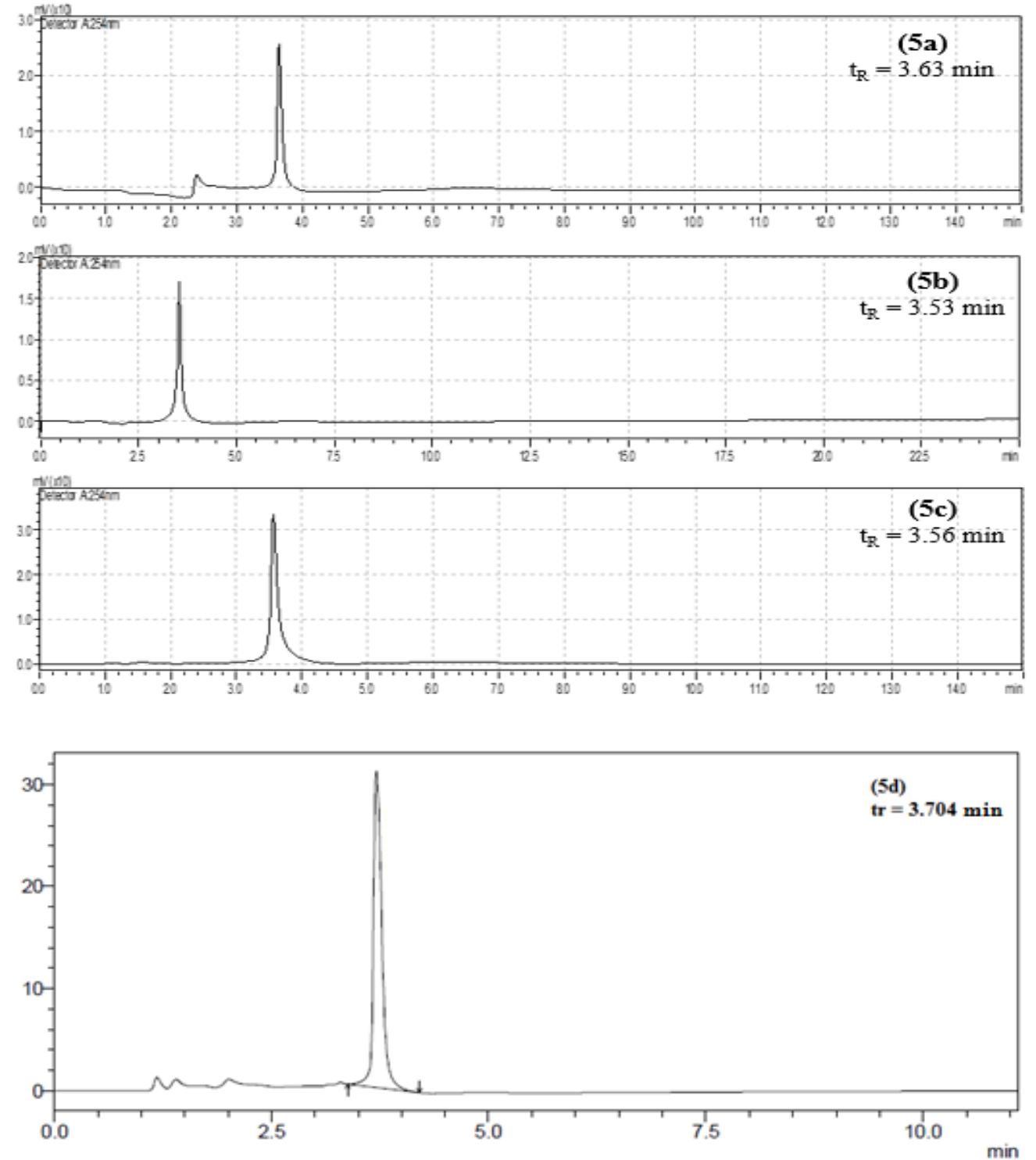


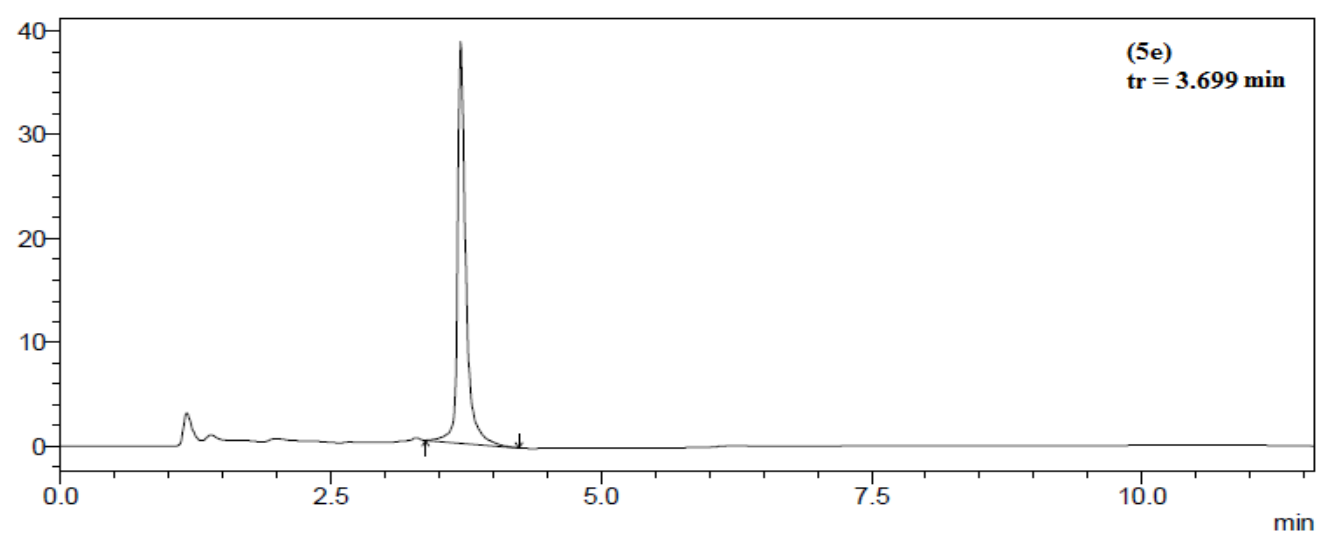

Figure S17. HPLC chromatograms of pyranopyrazoles 5a-e.

\section{Synthesis and characterization of the catalyst}

\section{Method for the preparation of Catalyst}

The synthesis of the nano-structured diphosphate $\mathrm{Na}_{2} \mathrm{CaP}_{2} \mathrm{O}_{7}$ has been carried by using the $\mathrm{Na}_{2} \mathrm{CO}_{3}, \mathrm{CaCO}_{3}$, and $\mathrm{NH}_{4} \mathrm{H}_{2} \mathrm{PO}_{4}$ in 1: 1: 2 proportions, respectively (purity of starting materials greater than 99\%). These chemicals were mixed in an agate mortar and progressively heated in a porcelain crucible. The synthesis of $\mathrm{Na}_{2} \mathrm{CaPO}_{7}$ particles was confirmed by powder XRD, IR, SEM, and TEM studies. The steps of $\mathrm{Na}_{2} \mathrm{CaPO}_{7}$ synthesis are summarized in figure S17.

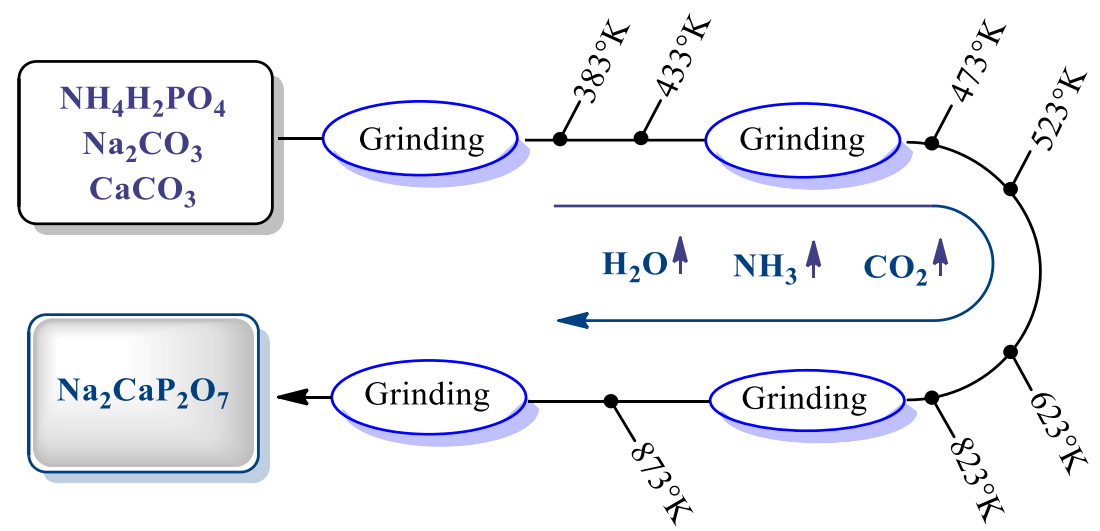

Figure S18. Steps of $\mathrm{Na}_{2} \mathrm{CaP}_{2} \mathrm{O}_{7}$ synthesis.

\section{XDR of the catalyst}

The powder obtained was analyzed by X-ray diffractometer, the diffractogram was recorded using a Bruker D8 Advance diffractogram. The spectrum of the $\mathrm{Na}_{2} \mathrm{CaP}_{2} \mathrm{O}_{7}$ diphosphate is reproduced in Figure S18 the crystallographic data obtained are gathered in table $\mathrm{S} 1$. The diffractometer uses copper anticathode radiation $\mathrm{Cu}-\mathrm{K} \alpha$ radiation: $\lambda=1.5406$ $\mathrm{A}^{\circ}$. The crystalline parameters were refined on a computer using the least-squares method via the AFPAR program. The acquisition is carried out at ambient temperature with a scanning mode $\theta / 2$ (and a Bragg angle $\theta$ spanning from $10^{\circ}$ to $50^{\circ}(17)$. 


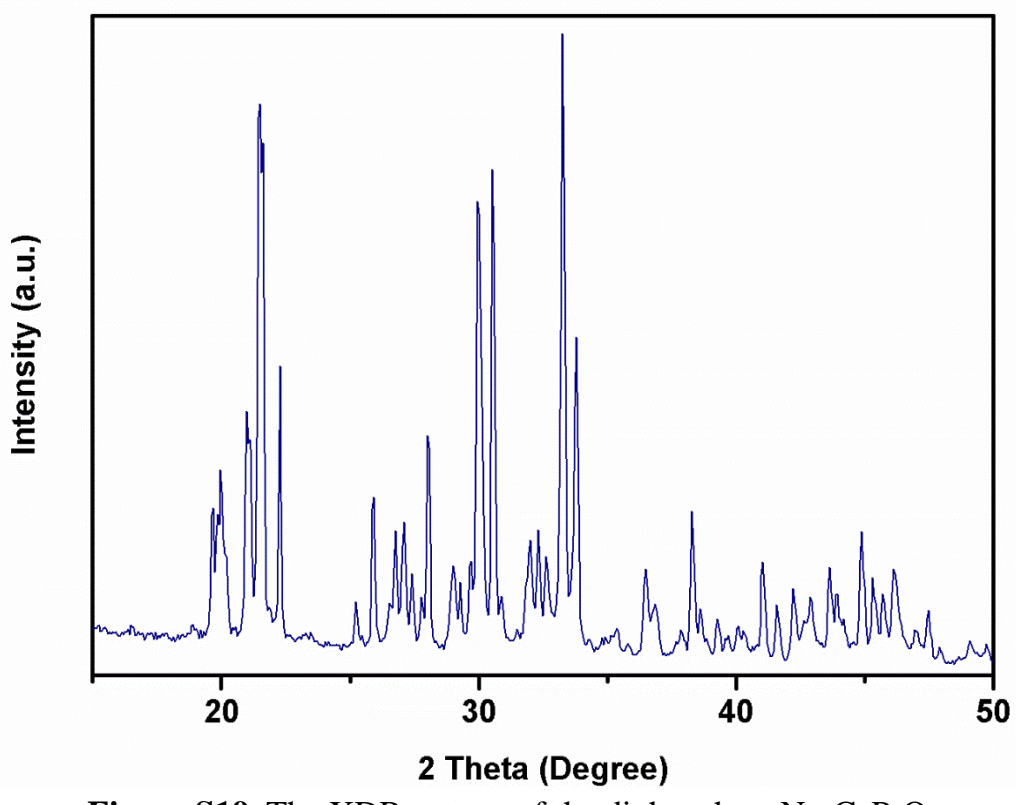

Figure S19. The XDR pattern of the diphosphate $\mathrm{Na}_{2} \mathrm{CaP}_{2} \mathrm{O}_{7}$.

Table S1. Allotment of the observed bands of $\mathrm{Na}_{2} \mathrm{CaP}_{2} \mathrm{O}_{7}$ analyzed by X-ray diffractometer.

\begin{tabular}{cc}
\hline \multicolumn{2}{c}{ Crystallographic data } \\
\hline Space group & Triclinic, $\mathrm{P} \overline{1}$ \\
$\mathrm{M}(\mathrm{g} / \mathrm{mol})$ & 260,0 \\
$\mathrm{a}(\AA)$ & 5.361 \\
$\mathrm{~b}(\AA)$ & 7.029 \\
$\mathrm{c}(\AA)$ & 8.743 \\
$\alpha\left({ }^{\circ}\right)$ & 69.4 \\
$\beta\left(^{\circ}\right)$ & 89.02 \\
$\gamma\left(\left(^{\circ}\right)\right.$ & 88.78 \\
$\mathrm{~V}\left(\AA^{3}\right)$ & 308.5 \\
$\mathrm{Z}$ & 2 \\
\hline
\end{tabular}

\section{Infrared of the catalyst}

The infrared spectrum of the diphosphate $\mathrm{Na}_{2} \mathrm{CaP}_{2} \mathrm{O}_{7}$ in powder form is shown in figure $\mathrm{S} 19$. The appearance of symmetrical vibration bands of $\mathrm{P}-\mathrm{O}-\mathrm{P}$ at $720 \mathrm{~cm}^{-1}$ and anti-symmetric vibration bands at $893 \mathrm{~cm}^{-1}$ confirm the existence of $\mathrm{P}_{2} \mathrm{O}_{7}$ (Figure S19). Two vibration fields have proved the presence of the $\mathrm{PO}_{4}$ group, the first at $996 \mathrm{~cm}^{-1}$ and $1031 \mathrm{~cm}^{-1}$ and the second going from1130 to $1278 \mathrm{~cm}^{-1}(17)$. 


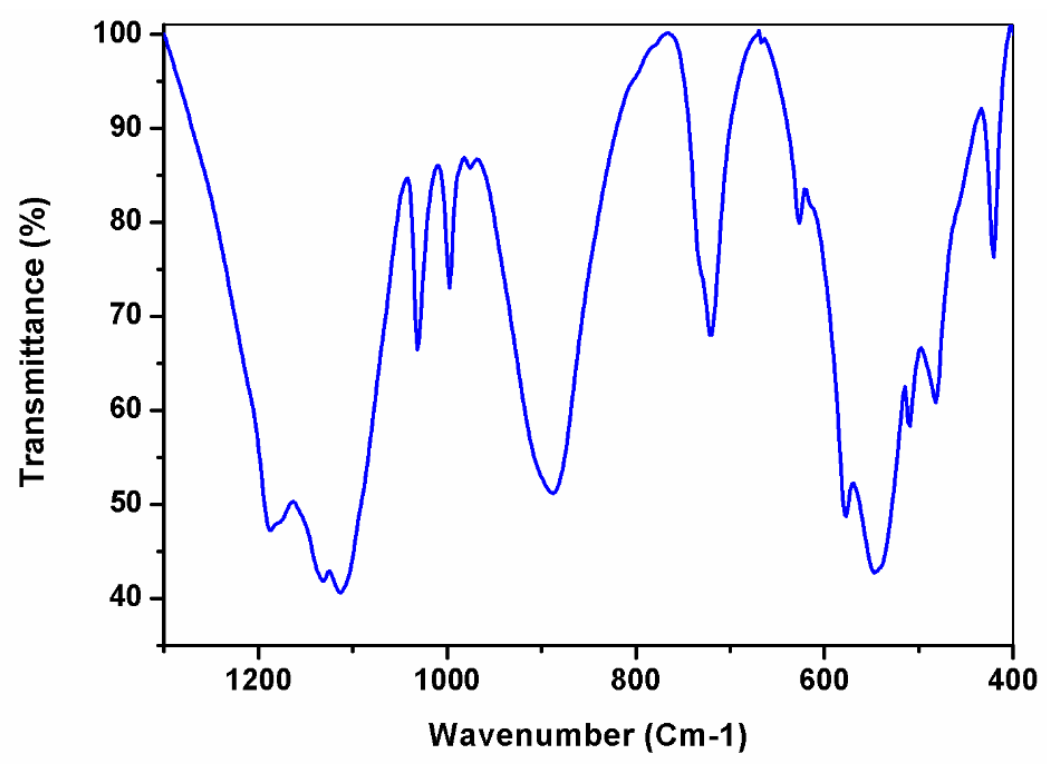

Figure S20. The infrared pattern of the catalyst was measured by using the FITR apparatus.

Table S2. Attribution of the observed bands of $\mathrm{Na}_{2} \mathrm{CaP}_{2} \mathrm{O}_{7}$ analyzed by FTIR spectroscopy.

$\left.\begin{array}{cc}\hline \text { Observed band }\left(\mathbf{c m}^{-1}\right) & \text { Awarding } \\ 407 & \\ 419 & \\ 483 & \\ 511 & \\ 548 & \\ 577 & \\ 626 & \\ 720 & \mathrm{v}_{\text {sym }}\left(\mathrm{P}_{7}\right) \\ 893 & \\ 996 & \mathrm{v}_{\text {antisym }}\left(\mathrm{P}^{-\mathrm{O}}\right) \\ 1031 & \mathrm{v}_{\text {sym }}\left(\mathrm{PO}_{4}\right) \\ 1130 & \\ 1175 & \\ 1278 & \mathrm{v}_{\text {antisym }}\left(\mathrm{PO}_{4}\right)\end{array}\right\}$ Vistortion vibrations

\section{TEM and SEM}

The morphological studies of the surface of $\mathrm{Na}_{2} \mathrm{CaP}_{2} \mathrm{O}_{7}$ are performed by using the scanning electron microscope HIROX SH-4000M. To visualize the microstructure of the $\mathrm{Na}_{2} \mathrm{CaP}_{2} \mathrm{O}_{7}$, Transmission Electronic Microscopy (TEM) was used on an FEI microscope operated at $120 \mathrm{kV}(17)$. 

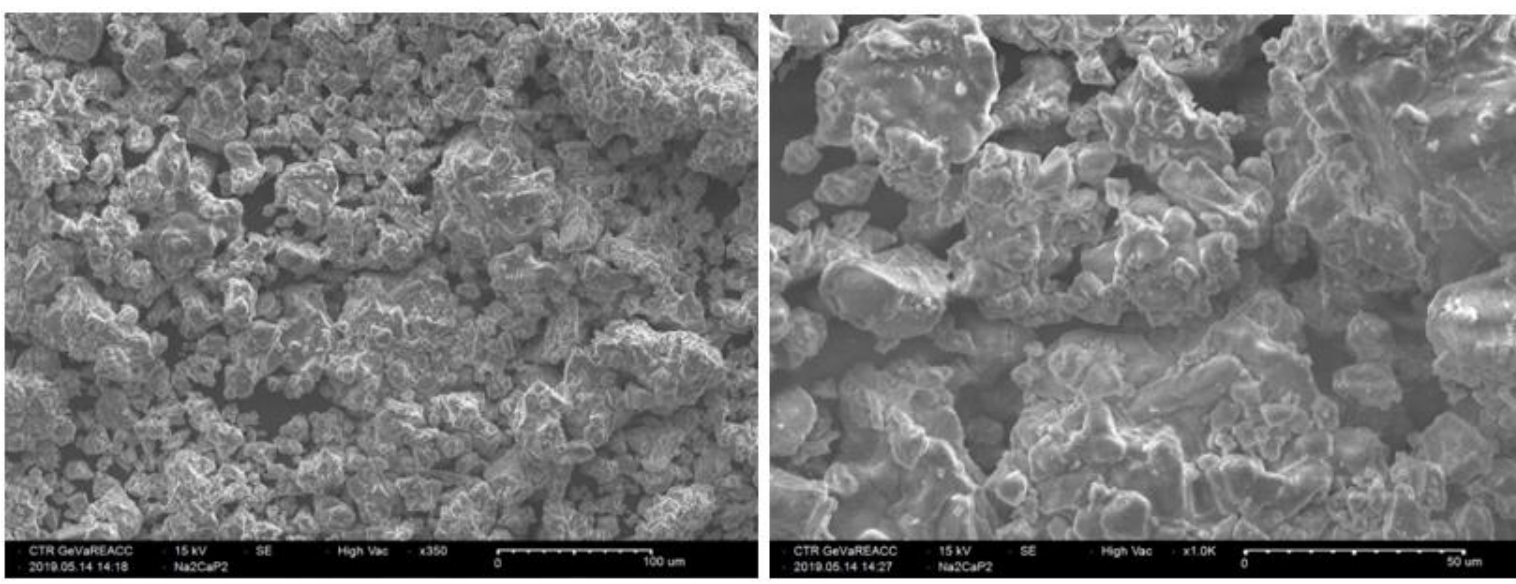

Figure S21. SEM images of $\mathrm{Na}_{2} \mathrm{CaP}_{2} \mathrm{O}_{7}$.
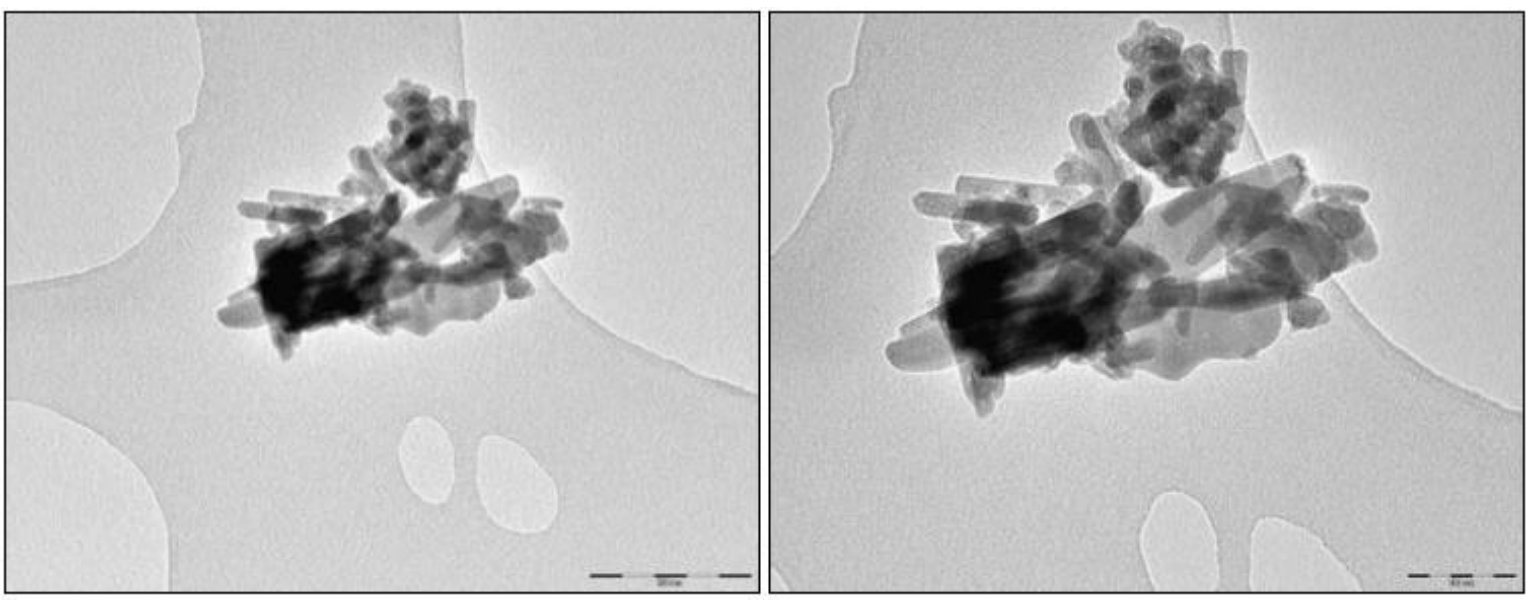

Figure S22. TEM images of $\mathrm{Na}_{2} \mathrm{CaP}_{2} \mathrm{O}_{7}$.

\section{ADMET/TOX screening}

Table S3. In silico physicochemical parameters for good oral bioavailability of synthesized compounds $\mathbf{5}(\mathbf{a}-\mathbf{e})$.

\begin{tabular}{ccccc}
\hline Compounds & Log P & MM & $\begin{array}{c}\text { Hydrogen } \\
\text { bond donor }\end{array}$ & $\begin{array}{c}\text { Hydrogen } \\
\text { bond acceptor }\end{array}$ \\
\hline 5a & 2.3 & $252.27 \mathrm{~g} / \mathrm{mol}$ & 2 & 4 \\
\hline 5b & 2.7 & $266.3 \mathrm{~g} / \mathrm{mol}$ & 2 & 4 \\
\hline $\mathbf{5 c}$ & 2.3 & $282.3 \mathrm{~g} / \mathrm{mol}$ & 2 & 5 \\
\hline $\mathbf{5 d}$ & 2 & $268.27 \mathrm{~g} / \mathrm{mol}$ & 3 & 5 \\
\hline 5e & 2.1 & $297.27 \mathrm{~g} / \mathrm{mol}$ & 2 & 6 \\
\hline
\end{tabular}

All the ADMET parameters were found to be favourable for all selected compounds $\mathbf{5}(\mathbf{a}-\mathbf{e})$.

Table S4. Drug likeness predictions of tested compounds 5(a-e).

Absorption

\section{Distribution}

\begin{tabular}{cccccc}
\hline & HIA $(\%)$ & $\begin{array}{c}\text { Cells Caco-2 } \\
\left(\mathbf{n m ~ s e c}^{-1}\right)\end{array}$ & MDCK & $\begin{array}{c}\text { Skin } \\
\text { Permiability }\end{array}$ & BBB \\
\hline $\mathbf{5 a}$ & 86.259135 & 8.35134 & 122.163 & -4.29465 & 0.727216 \\
\hline $\mathbf{5 b}$ & 86.801884 & 0.414056 & 198.378 & -4.23184 & 1.07902 \\
\hline $\mathbf{5 c}$ & 86.421462 & 7.08002 & 56.5433 & -4.43997 & 0.565816 \\
\hline $\mathbf{5 d}$ & 76.953830 & 21.1136 & 47.9383 & -4.48835 & 0.397176 \\
\hline $\mathbf{5 e}$ & 68.466285 & 17.972 & 31.1239 & -4.3418 & 0.673673 \\
\hline Ampicillin & 81.478448 & 0.630713 & 0.937589 & -5.03574 & 0.0587946 \\
\hline
\end{tabular}


HIA: Human intestinal absorption (HIA, \%); BBB: in vivo blood-brain barrier penetration (C.brain/C.blood); Caco2 cell: in vitro Caco-2 cell permeability ( $\mathrm{nm} / \mathrm{sec})$; MDCK: in vitro MDCK cell permeability (Mandin Darby Canine Kidney)

Intestinal absorption has been predicted to be more than $80 \%$ for compounds 5a $(86.25 \%) \mathbf{5 b}(86.8 \%)$ and $\mathbf{5 c}(86.42 \%)$, which is greater than reference drugs Ampicillin $(81.478 \%)$. 